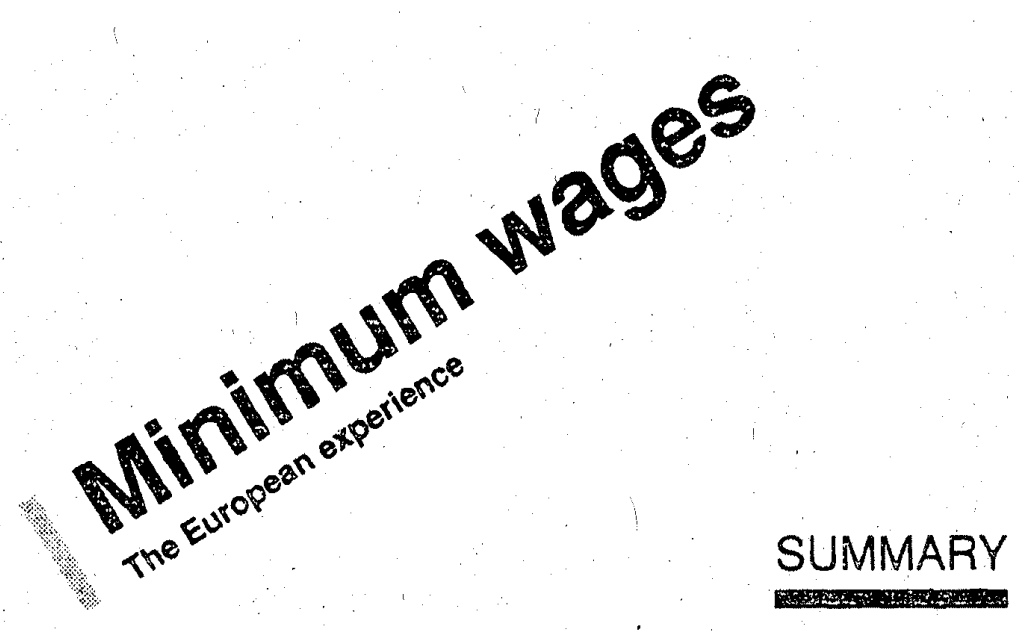

Opponents of minimum wages argue that they hurt jobs in Europe; supporters say that they combat exploitation and help the poor. We try to sort out myth from reality. Differing policy prescriptions reflect different views of how the labour market actually works. Contrary to popular wisdom, it is as easy to make a theoretical case against minimun wages as for them. Evidence, not theory, is what is needed now.

Relative to average wages, minimum wages have not risen in Europe over the last 30 years; they caused higher unemployment only if they prevented a necessary fall in the wages of the low paid. Second, minimum wages for young workers are often a lower proportion of average eamings in Europe than in the USA. Third, we find no general evidence that minimum wages reduced employment, except perhaps for young workers. The (good or bad) effect of minimum wages has been exaggerated.

- Juan Dolado, Francis Kramarz, Stephen Machin, Alan Manning, David Margolis and Coen Teulings 


\title{
The economic impact of minimum wages in Europe
}

\author{
Juan Dolado, Francis Kramarz, Stephen Machin, \\ Alan Manning, David Margolis and Coen Teulings
}

Bank of Spain; CREST, INSEE; University College, London and Centre for Economic Performance, LSE; Centre for Economic Performance, LSE; University of Montreal; University of Amsterdam

\section{INTRODUCTION}

The minimum wage is a controversial policy. Its proponents typically argue that it helps prevent the worst excesses of exploitation in the labour market, and brings the living standards of the lowest paid up to some minimum acceptable standard; its opponents argue that it may price low-skill workers out of jobs, and that many of those typically affected by the minimum wage do not live in poor households. The economics of the minimum wage has recently been the subject of renewed interest for two reasons.

First, the minimum wage is widely seen as one of the labour market institutions causing high and persistent unemployment in Europe. As unemployment rose up the policy agenda, interest in the minimum wage revived. The recent $O E C D$ fobs Study (OECD, 1994) recommended, in an uncharacteristically forthright statement, that the member countries should

Reassess the role of statutory minimum wages as an instrument to achieve redistributive goals and switch to more direct instruments. If it is judged desirable to maintain a legal

\section{\%: $: \%: \%$}

We would like to thank Peter Burgess, Ana Rute Cardoso, Richard Dickens, Susan Harkness, Claudio Lucifora, Costas Xanellopoulos, Joep Konings, Steve Mcintosh, Erik Strojer Madsen, Marco Manacorda, Sally Marullo, Christoph Schmidt, Henn Sneessens, Etienne Wasmer and Fredrik Wulfsberg for help with this paper, and Jim Sesil in particular for his research assistance. We would also like to thank the Exonomic Policy Panel and especially David Begg, Michael Keen and Gilles Saint-Paul for their comments. 
minimum wage as part of an anti-poverty strategy, consider minimising its adverse employment effects, including:

- Indexing it to prices, rather than average earnings

- Ensuring sufficient differentiation in wage rates by age and region to prevent the minimum wage from harming employment prospects for young people or lown. productivity regions.

Second, the cosy consensus among economists about the employment effect of the minimum wage - summarized in the survey of Brown et al. (1982) as 'a $10 \%$ increase in the minimum wage reduces teenage employment by 1 to $3 \%$ ', though with no indentifiable effect on the adult labour market - has been challenged by new research. Card and Krueger (1995) examine evidence on the employment fiffects of the minimum wage in the USA using a number of different data sources and methods, and conclude that

recerit minimum-wage increases have not had the negative employment effects predicted ... Some of the new evidence points towards a positive effect of the minimum wage on employmeri; most shows no effect at all. Moreover, a reanalysis of previous minimumwage studies finds little support for the prediction that minimum wages reduce employment.

These conclusions have not gone unchallenged (see, for example, the reviews: of Card and Krueger in the Industrial and Labor Relations Review, July 1995; papers on the minimum wage in the American Economic Review, May 1995; Neumari and Wascher, 1995; and Schmitt, 1996). The final verdict is not yet in.

We aim to assess the effect of minimum wages in Europe, cutting through the emotive positions of proponents and opponents to offer a more balanced assessment of its impact in different countries; there is no substitute for a careful study country by country. However, one paper cannot consider all European countries. We start with a brief description of the minimum wage systems currently in operation in a range of countries, then focus on four: France, the Netherlands, Spain and the UK. Each has some intrinsic interest, but their experiences have broader lessons: France is often cited as an object lesson in the adverse effects of very high leveis of the minimum wage, the Netherlands had a large cut in youth minimum wages in the early 1980 s, Spain had a very large rise in the youth minimum wage in 1990, while the UK abolished all minimum wages (except in agriculture) in 1993.

We start with a brief description of the minimum wage systems in operation in the countries of western Europe and assess their impact on the wage distribution. We then consider the theory about the minimum wage, arguing that many common perceptions about the minimum wage are at best half-truths. We try to paint a more

\section{\%.:. .}

'Neumars and Wascher received a lot of publicity, but their continued reluctance to make their data available makes it hard to evaluate their contribution. 
balanced picture. Our discussion is informal, but its claims are backed up by a formal model sketched in a Technical Appendix. Our four country studies focus mainly on the crucial issue of the employment effects of minimum wages. Finaily, we offer policy conclusions.

\section{MINIMUM WAGES IN EUROPE}

The systems of minimum wages in operation in most European countries are summarized in Table 1. There are five main types of system. First, a statutory minimum can be set by government (possibly in consultation with employers and unions), as in France, Spain, the Netherlands, Portugal and Luxembourg. Second, as in Belgium, Greece and Denmark, a national minimum wage can be set as part of national collective bargains. Third, different minimum wages can be determined in sectoral collective agreements (generally extended to employers who were not party to the original agreements), as in Germany, Italy, Austria and, to some extent, Switzerland. Fourth, as in Sweden, Norway and Finland, collective agreements can cover effectively everybody and generally contain minimum rates without any formal provision for extension of these rates to non-signatory employers. Finally, as in Ireland and the UK (prior to 1993), minimum wages can be set in selected lowpaying industries.

There is also considerable variation in how many different minima are set: most countries have variation by age; some have variation across region, occupation, industry, job tenure, size of firm, and even marital status and number of dependants.

One would like some measure of the importance of the minimum wage in the wage determination process. The real level of the minimum wage may be inappropriate in comparisons across time or between countries with differing productivity: we expect the effect of minimum wages to depend on their level relative to labour productivity. The commonest measure is therefore the minimum wage as a fraction of average earnings, known in the USA as the Kaitz index (often weighted to allow for the fact that not all workers are covered by minimum wage laws). The Kaitz index is analogous to the most widely accepted measure of the impact of the wage floor provided by welfare benefits: namely, the replacement ratio.

Table 1 presents estimates of the Kaitz index for as many countries as possible (the USA is included as a comparison). Minimum wages in most European countries are about $50-70 \%$ of average earnings compared to about $33 \%$ in the USA. In countries with a number of different minimum wages, there are obviously difficulties in computing a single measure of the Kaitz index. Measures are therefore a general indication of minimum wages rather than precise estimates. This is a particularly serious problem in countries like Germany and Italy, which have a very large number of minimum rates that may be very different. In countries with a single statutory minimum, the effective Kaitz index will be much higher for less skilled 
Table 1. Minimum wage systems in Europe and the USA

\begin{tabular}{|c|c|c|c|c|c|c|}
\hline Country & Determination & Variation by: & $\begin{array}{l}\text { Kaitz } \\
\text { indcx } \\
\text { (year) }\end{array}$ & $\begin{array}{l}\% \text { of workers } \\
\text { at or near } \\
\text { minimum }\end{array}$ & $\begin{array}{l}\text { Youth minimum as } \% \text { of adult } \\
\text { minimum }\end{array}$ & $\begin{array}{l}\text { Replacement } \\
\text { ratio }\end{array}$ \\
\hline $\begin{array}{c}\text { Belgiam } \\
.\end{array}$ & $\begin{array}{l}\text { Negotiated by unions and } \\
\text { employers as part of national } \\
\text { agreement }\end{array}$ & Age, job tenure & $\begin{array}{l}0.60 \\
(1992)\end{array}$ & $4 \%$ & $\begin{array}{l}\text { Sinall reduction for }<23 \text { (lower } \\
\text { rates for short job tenure) }\end{array}$ & 0.6 \\
\hline Denmark & $\begin{array}{l}\text { Negotiated as part of collective } \\
\text { agreements }\end{array}$ & Industry, age & $\begin{array}{c}0.54 \\
(1994)\end{array}$ & $6 \%$ & $40 \%(<18)$ & 0.9 \\
\hline Finland & $\begin{array}{l}\text { Negotiated as part of collective } \\
\text { agrcements }\end{array}$ & Age, occupation, industry, region & $\begin{array}{c}0.52 \\
(1993)\end{array}$ & & & 0.63 \\
\hline France & $\begin{array}{l}\text { Set by government constrained by } \\
\text { formula }\end{array}$ & Age, training & $\begin{array}{c}0.50 \\
(1993)\end{array}$ & $11 \%$ & $\begin{array}{l}80 \% \text { (age } 16) ; 90 \% \text { (age } 17)+ \\
\text { schemes }+30-75 \% \text { for trainees }\end{array}$ & 0.57 \\
\hline Greece & $\begin{array}{l}\text { Part of national collective } \\
\text { agreement }\end{array}$ & $\begin{array}{l}\text { Manual/non-manual, job tenure, } \\
\text { marital status, qualifications }\end{array}$ & $\begin{array}{c}0.62 \\
(1995)\end{array}$ & $20 \%$ & Lower rates for short job tenure & \\
\hline Ireland & $\begin{array}{l}\text { Joint Labour Committees in } 16 \\
\text { low-paying industries }\end{array}$ & $\begin{array}{l}\text { Age, industry, region, occupation, } \\
\text { job tenure }\end{array}$ & $\begin{array}{c}0.55 \\
(1993)\end{array}$ & & $\begin{array}{l}\text { Varies; } 63 \%(<18) ; 81 \%(<21) \text { in } \\
\text { hotels }\end{array}$ & 0.37 \\
\hline
\end{tabular}




\begin{tabular}{|c|c|c|c|c|c|c|}
\hline Italy & $\begin{array}{l}\text { Extension of collective } \\
\text { agrements }\end{array}$ & Age, industry, job tenure & $\begin{array}{c}(0.7) \\
(1991)\end{array}$ & & Embodicd in industry agrcements & 0.20 \\
\hline Luxcmbourg & Statutory minimum wage & Agc, skill, family characteristics & 0.56 & $11 \%$ & $70 \%(<21)$ & \\
\hline Netherlands & Statutony minimum wage & Age & $\begin{array}{c}0.55 \\
(1993)\end{array}$ & $3,2 \%$ & $\begin{array}{l}34.5 \% \text { (age } 16) \text { rising to } 84 \% \\
\text { (age } 22 \text { ) }\end{array}$ & 0.70 \\
\hline Norway & $\begin{array}{l}\text { Negotiated as part of collective } \\
\text { agtcements }\end{array}$ & Industry, agc, job tenure, job & $\begin{array}{c}0.64 \\
(1993)\end{array}$ & & & 0.65 \\
\hline Portugal & Statutory minimum wage & Age, traince status, industry & $\begin{array}{r}0.45 \\
(1993)\end{array}$ & $8 \%$ & $75 \%(<18)$ & 0.65 \\
\hline Spain & Statutory minimum wage & Age, homeworkers, casual workers & $\begin{array}{c}0.32 \\
(1994)\end{array}$ & $6.5 \%$ & $66 \%(<18)$ & 0.70 \\
\hline Sweden & $\begin{array}{l}\text { Negotiated as part of collective } \\
\text { agrecments }\end{array}$ & $\begin{array}{l}\text { Age, industry; joh tenure, } \\
\text { occupation }\end{array}$ & $\begin{array}{l}0.52 \\
(1992)\end{array}$ & $0 \%$ & $85 \%(<24)$ & 0.80 \\
\hline Switzerland & $\begin{array}{l}\text { Industry-level collcctive } \\
\text { agrceinents (coverage } 30 \% \text { ) }\end{array}$ & Age, industry & $\begin{array}{c}0.52 \\
(1993)\end{array}$ & & Enbodicd in industry agrecments & 0.70 \\
\hline $\begin{array}{l}\text { United } \\
\text { Kingdom }\end{array}$ & $\begin{array}{l}\text { P're- } 1993 \text { sct by Wagcs Councils } \\
\text { by industry; now only } \\
\text { agriculturc }\end{array}$ & $\begin{array}{l}\text { Age, industry (more complex } \\
\text { pre-1986) }\end{array}$ & $\begin{array}{c}0.40 \\
(1993)\end{array}$ & & $0 \%(<21)(1986-93)$ & 0.38 \\
\hline United States & $\begin{array}{l}\text { Fecleral minimum wage (higher } \\
\text { in some statcs) }\end{array}$ & Limited youth sub-minimism & $\begin{array}{c}0.39 \\
(1993)\end{array}$ & $4 \%$ & No raduction & 0.50 \\
\hline
\end{tabular}

Note: We are grateful to Ana Rute Cardoso, Costas Kanellopoulos, Claudio Lucifora, Joep Konigs and Erik Madsen for help in compiling this table.

Sources: Primcipally the European Industral Relations Review and $I L O$ Yearbook of Labour Statistics. Further ret ails available from the authors. 
than for more skilled workers because the numerator in the index is the national minimum. But in countries where there are many different minimum rates, this is not necessarily the case because the minimum rate is generally lower for less skilled workers and the gap in the minimum rates can be very large. In both Italy and Germany, the highest minimum rate is over three times the lowest minimum rate, so that although the average Kaitz index for Italy looks extremely high (75\%); the Kaitz index for low-paid workers is only slightly higher.

Given a higher minimum wage, relative to average earnings, in Europe than the USA, minimum wages might cause job losses in Europe even if they do not in the USA. It is tempting to blame high European unemployment at least in part on high minimum wages. But this may be mistaken. Many commentators feel that the effect of minimum wages is strongest in the youth labour market. The USA has little Srovision for the payment of lower minimum wages to young workers (the evidence suggests that the restrictive youth sub-minimum is not widely used), but most European countries have extensive variation in the minimum by age (see Table 1 , noting that a number of countries, especially Belgium and Greece, vary the minimum wage by job tenure, which has the effect of leading to lower minimum wages for young workers). Given this variation in the use of the youth minimum, the variation in the Kaitz index for teenagers across countries differs from that for adults, the US level (85\%) being much higher in 1992 than in many European countries (e.g. Spain 50\%, Sweden 80\%)

Although the Kaitz index is the most widely used measure of the impact of the minimum wage, concerns are expressed about its use as a measure of the impact of minimum wages. First, a rise in the minimum wage will generally affect the average wage; in the extreme case of a corresponding induced percentage increase in the average wage, the Kaitz index would be unchanged. Typically, of course; the induced effect on the wages of higher-paid workers will be smaller, so the Kaitz index will rise. Both theory (see the Technical Appendix) and the available evidence suggest that this is the case (see Grossman (1983) for the USA; Bazen and Martin (1991) and Bazen et al. (1995) for France; and Dickens et al. (1994a) for the UK): a 10\% rise in the minimum wage raises the average wage by at most $3 \%$, although effects on the average wage in the youth market are, of course, larger. If European labour market institutions make it easier to transmit rises in the minimum wage to further up the wage structure, it is dangerous to compare Kaitz indices across continents or even perhaps across countries; it is safer to use it to analyse changes over time in a given country.

Second, the Kaitz index only measures the impact of the minimum wage on the structure of earnings (minimum relative to average). It cannot directly measure whether wage costs as a whole are too high in Europe because of labour market institutions such as the minimum wage. However, it has recently become more fashionable to argue that European labour market institutions interfere with the structure of wages in a way which leads to poor labour market performance (see, for example, OECD, 1994). The Kaitz index is well suited to analysing this argument. 
Third, the Kaitz indices in Table 1 take no account of taxes paid by employers and workers which may be important in understanding the problems of European labour markets. One could compute a producer Kaitz index (the ratio of the cost of minimum wage labour to the cost of 'average' labour for an employer) or a consumer Kaitz index (the real take-home wage of a minimum wage worker relative to the 'average' worker). These differ from the Kaitz indices presented here only to the extent that the tax system is not proportional. As taxes on workers are generally progressive, the Kaitz index used here will generally understate the consumer Kaitz index. But employer payroll taxes are regressive in many countries, in which case our measure of the Kaitz index will understate the producer Kaitz index.

If higher employer payroll taxes are especially bad for employment in the presence of minimum wages, can the Kaitz index pick this up? For example, concern is often expressed in France that the level of employer payroll taxes rose from $27 \%$ in 1950 to $44 \%$ in 1992 . Workers paid above the minimum can partly absorb an increase in payroll taxes through accepting lower wages than they would otherwise have done, mitigating the rise in labour costs for employers: Workers paid the minimum wage cannot. But then the Kaitz index rises because its denominator has fallen, so the index is perfectly capable of detecting such effects.

Finally, measures of the ratio of the minimum to average earnings may misrepresent the effect of minimum wages where other institutions - benefit systems and collective bargaining - provide other floors to wages. Another common measure of the impact of minimum wages is the fraction of workers paid at or close to the minimum wage. In many sectors with a minimum wage, there is a noticeable spike in the wage distribution at the minimum wage; the larger this spike, the more likely the impact of the minimum wage on the wage distribution. The Kaitz index and the spike may give different impressions of the importance of minimum wages. In Sweden, the Kaitz index is higher than in the USA, but other institutions compress the wage distribution so strongly that nobody actually receives the minimum (Ostros, 1994) ${ }^{2}$. Some estimates of the spike are also presented in Table 1: they tend to be in the region 5-10\%. In order to give some idea of the comparison of minimum wages and benefits as a floor to wages, we also include a measure of replacement ratios.

Table 1 refers only to the minimum wage at a point in time, but its importance may change over time. Figure 1 presents the Kaitz index for a number of countries. Although minimum wages have risen substantially in all of our countries, this has been broadly in line with the increase in average earnings: there are few dramatic changes in the Kaitz index in European countries. It is hard to argue from this that aggressive increases in minimum wages caused the spectacular

\section{\%: : : :}

The model of the Technical Appendix shows that the relationship between the Kaitz index and the spike would be expected to depend on the dispersion of eamings. 

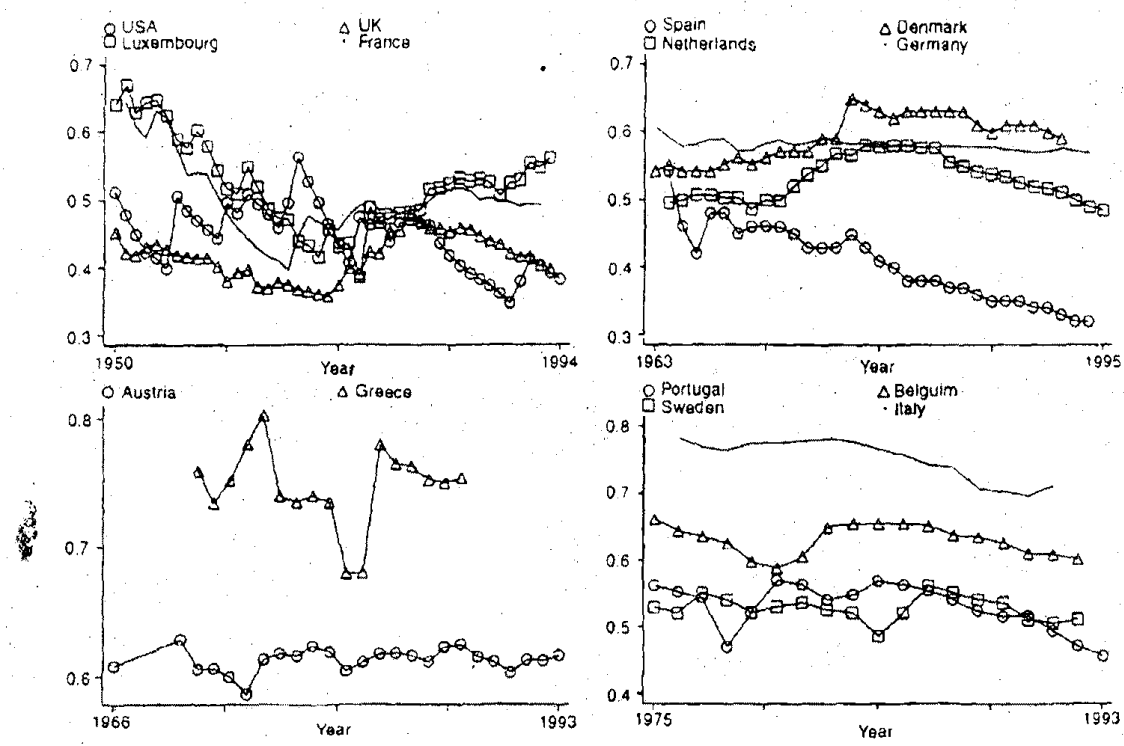

Figure 1. Kaitz index in selected countries Sources: Available from the authors.

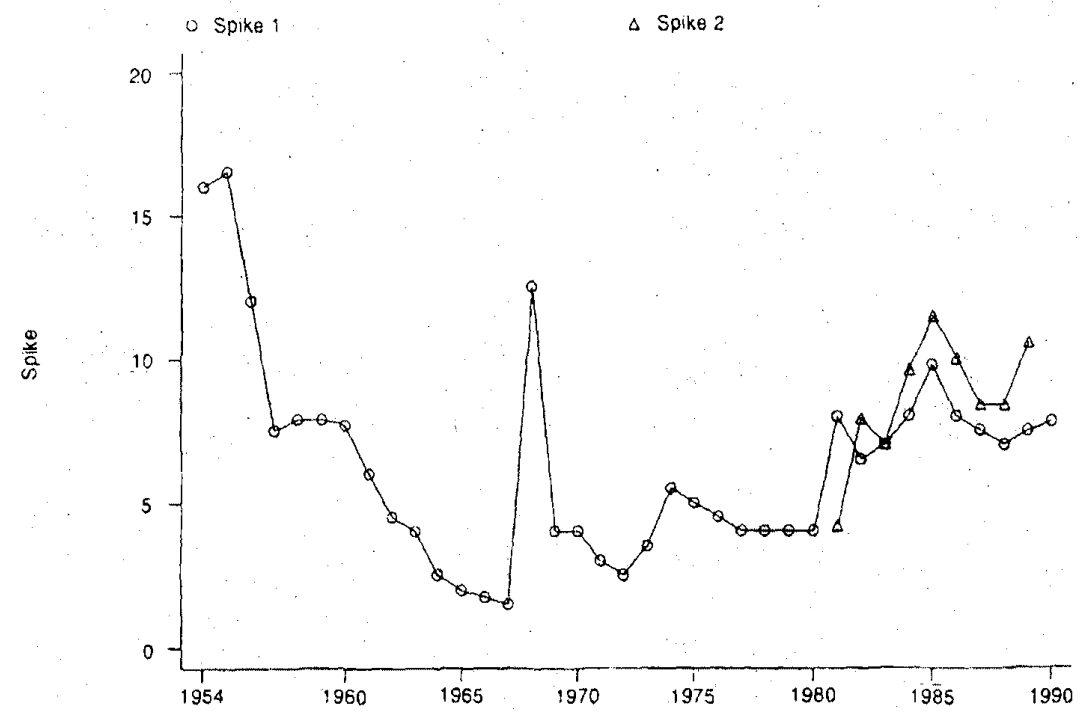

Figure 2. The evolution of the spike in France

Notes: Spike 1, taken from the annual ACEMO series reported in Combault (1995), measures the proporion of workers at end-June earning berween the old and new SMIC. Spike? is an estimate of the proportion of workers in the Enquête Emploi who repor eamings in the band which contains the SMIC multiplied by their usual hours of work (actual earnings are not reported). 
rise in European unemployment. But failure to decrease the index in response to changed market circurnstances might still have had an effect. Powerful forces such as globalization and skill-biased technical change in all OECD countries may require widening the wage distribution (see OECD (1994) for a forceful statement of this view).

Although minimum wages may be a constant fraction of average earnings, they may be a rising fraction of the earnings of those workers affected. If so, we would expect to see evidence of a rising proportion of workers paid at or near the minimum, or a more general compression of wages at the bottom of the distribution. Unfortunately, it is hard to get estimates of changes in the spike for most countries. We have two estimates for France (Figure 2). Both show some rise in the spike in the 1980 s, consistent with the view that the minimum wage now has a bigger impact than in the 1970s (although the highest levels of the spike were in the 1950s, which also had the highest Kaitz index). But given the ongoing debate about whether trends against the less skilled are the main explanation of rising unemployment (see Nickell and Bell, 1995; Card et al. 1995), we conclude that there is no strong evidence that minimum wages are a more serious constraint on the European economies than 30 years ago.

\section{THE ECONOMICS OF THE MINIMUM WAGE}

The conventional wisdom about the implications of standard economic theory can be encapsulated in five propositions:

- A minimum wage cannot increase employment and generally reduces it.

- Its adverse employment effects are largest in a small open economy where international competiveness is most significant.

- Lower tax rates or higher subsidies are a better way to improve both the employment prospects and the incomes of the low paid.

- Young workers are most affected.

- Minimum wage earners do not usually come from the poorest households, so minimum wages do little to alleviate poverty.

Is this picture accurate? Our discussion will be largely informal, but it is based on a formal model of the labour market in the Technical Appendix. Firms are heterogeneous, so that different firms are affected in different ways by the minimum wage.

\subsection{Economic theory predicts that minimum wages must reduce employment}

Predictions of economic theories are almost always sensitive to assumptions. We are surprised by an unconditional claim like the one made above and sceptical that 
anyone actually believes it. Yet it pervades analysis of the minimum wage. Consider the OECD Jobs Study (OECD, 1994). On page 49 it states:

A number of full-time workers in Canada are estimated to have received hourly wages below the average minimum in 1987, but there is a clear jump in the number of young persons once the minimum wage was passed. While this suggests that legislation has impeded employment for young people in Canada, there is little evidence of any jumps in the wage distribution in the United States in 1987. This in turn would call into doubt any negative employment effects of the minimum wage in that year

and on the following page:

The link between minimum wages and youth wages in France and Canada ... does tend

to indicate the potential for a negative impact on employment of statutory wage floors.

This argument is based on the familiar competitive labour market model in which firms have to pay the market wage and workers get paid their marginal product, as in Figure 3a. If the labour market clears in the absence of a minimum wage, a binding minimum wage $\left(W_{1}\right)$ must reduce employment from $\mathcal{N}_{0}$ to $\mathcal{N}_{1}$. The employment loss from a given minimum wage will be larger the more elastic is the demand for labour.

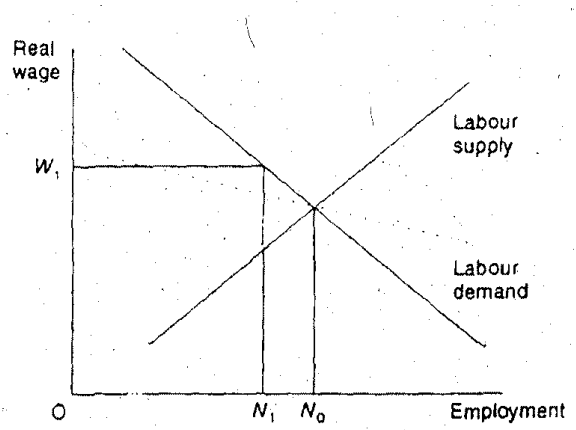

Figure 3a. Minimam wages and employment in a competitive labour market

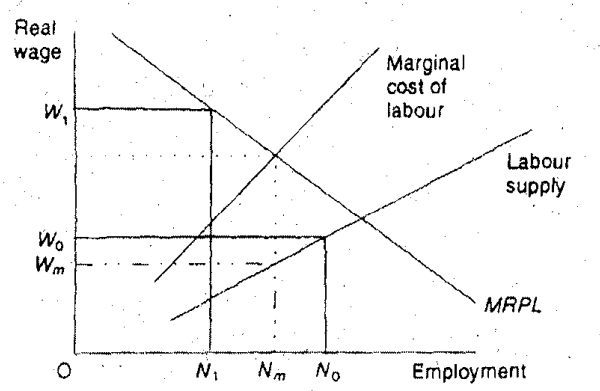

Figure 3b. A raomopsonistic labour market 
However, embedding analysis of the effect of a minimum wage within a labour market assumed to be perfectly competitive is not the only possibility; it is less well known that within other contexts a minimum wage may raise employment. Labour market textbooks show how this occurs under monopsony, where there is a single buyer of labour. The employer can choose what wage to pay, a higher wage bringing forth a higher supply of workers. A profit-maximizing employer will choose the level of employment where the marginal product of an extra worker is equal to the marginal cost of an extra worker, which exceeds the wage: attracting the extra worker requires raising wages also for existing workers. ${ }^{3}$ Hence each worker gets paid a wage below his or her marginal product: it is this gap which allows the minimum wage to raise the wage of workers without entirely removing their profitability to firms.

Consider the monopsonistic labour market in Figure 3b. In the absence of a minimum wage, wage and employment will be at $W_{m}$ and $\mathcal{N}_{m}$. A binding minimum wage at $W_{1}$ makes the marginal cost of labour to the firm flat until it hits the labour supply curve (hiring extra workers no longer requires raising the wage). Previously, the employer chose low wages and suffered the consequence of low employment; but the low-wage option is no longer allowed and so the employer might as well take on the extra workers forthcoming at the minimum wage. However, there is a limit to how high the minimum wage can be set without hurting employment. Employment. is maximized when the minimum wage is set at the level that would prevail in a competitive labour market (where the labour supply and MRPL curves cross). Attempting to raise the minimum wage still further will result in employment losses (relative to the maximum attainable). The extent to which minimum wages can be raised without destroying jobs depends on both the elasticity of the labour demand curve and the elasticity of the labour supply curve facing the firm, with minimum wages being more effective the more elastic is the labour demand curve

Of course, the level of wages that would prevail in a competitive market will differ across segments of the labour market; it might be lower for young workers and in some regions. A single national minimum wage is then an extremely blunt policy instrument, being set too low in some markets (employment could be raised by having a higher minimum) and too high in other markets (employment is reduced). If there are forces leading to wider dispersion in wages, this problem will worsen over time and will act as a constraint on the minimum wage. It is better to vary the minimum wage across labour markets where the competitive wage is expected to differ, notably by age or region. It is also possible that any binding minimum wage reduces employment even though all labour markets are monopsonistic. This could occur where the labour supply to the market as a whole is inelastic, but where that to the individual firm is more elastic (see the Technical Appendix for more details).

\section{\%..........}

${ }^{3}$ Uniess a different wage can be paid to each and every worker. While employers can partially discriminate across workers, perfect discrimination is implausible. 
Having explained monopsony, most labour economics textbooks then argue that few employers are a single purchaser of labour and hence monopsony is extremely rare. This conclusion is seriously misleading. The important features of monopsony will be reproduced in any situation where firms have some discretion over the wages they pay. For example, it is plausible to think that the higher the wage that a firm pays, the easier it finds it to recruit and retain workers. Put this way, it is perfect competition that is the extreme and implausible outcome, with its assumption that an employer which cuts wages by even a fraction of an ecu will find that all its workers immediately leave. Nobody would support such an extreme view; and anything else is monopsony. The important question is the extent of monopsony

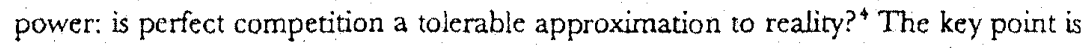
that economic theory has no unambiguous prediction about the employment effects of minimum wages. Empirical research is required.

There are other theoretical arguments why a minimum wage might raise employment. Calvo and Wellisz (1979) argue that, as a furm grows in size, it becomes more expensive to monitor workers and hence the average cost of labour rises (this makes these models akin to monopsony models), an idea recently revived by Rebitzer and Taylor (1995). In efficiency wage models more generally; where the productivity of labour depends on the wage paid, the minimum wage may raise employment (Manning (1995) provides a general condition). One can also make a case for a minimum wage even if it reduces employment for some workers. Cahuc and Michel (1996) present a model in which a binding minimum wage will price some workers out of the market unless they raise their productivity to the level of the minimum by education and training; the effect of the minimum wage is that some workers undertake training they would otherwise not have done. This is an outcome that is socially desirable because their model is set up so that there is some underinvestment in training. One should note that it has also been argued that the minimum wage discourages training, and that models can be constructed in which this is the case. The conclusion should be that a perfectly literate economic argument can be made for or against a minimum wage. Theory alone will not resolve the debate: evidence is what is needed. Where and how should one look?

We provide a brief description of the main methods that have been used together with an assessment of their respective strengths and weaknesses. We will argue that there is a danger in routinely applying US methodology to Europe: there are good reasons why the approaches are less likely to be successful on this side of the Atlantic.

One approach is simply to look at the correlation of employment changes with minimum wage changes, controlling for other relevant factors. This approach

\section{\%}

"Is there other evidence for monopsony power in labour markets? Proponents argue that the existence of equilibrium wage dispersion, the employer-size wage effect, discrimination, the eamings losses suffered by displaced workers, and the general training paid for by employers are all explained most plausibly by labour market frictions which are the. source of monopsony power. Opponents claim that other explanacions can be found for these empirical findings. 
typically exploits variation in minimum wages (or more commonly the Kaitz index) over time and/or across industries and regions. The approach has a very simple interpretation (the Technical Appendix provides some justification), but also some potential weaknesses. First, it is difficult to control fully for other supply and demand factors that affect employment, and the Kaitz index will pick up the effect of omitted supply and demand factors (the denominator in the Kaitz index is the average wage, which will be affected by demand and supply shocks). So it is important to establish that the variation in the Kaitz index is driven primarily by variation in the minimum wage. The approach has also been criticized for failing to recognize the endogeneity of the minimum wage (e.g. some have argued that the minimum wage is increased faster in good times). The seriousness of this problem is a matter of debate: minimum wages may be set a considerable time before they take effect, and one might question the economic sophistication of the process by which they are often set.

A second general approach (fashionable in recent years) is to exploit 'natural experiments': episodes in which minimum wages were raised. Most notable is the study by Card and Krueger (1994) of the rise in the minimum wage from $\$ 4.25$ to $\$ 5.05$ in New Jersey in April 1992 on employment in fast-food restaurants. As a control group, unaffected by minimum wage changes but facing other relevant shocks, Card and Krueger used the experience of restaurants in neighbouring parts of Pennsylvania. This type of methodology is easier to apply in the USA (and also Canada): quoting Judge Louis Brandeis, 'it is one of the happy incidents of the federal system that a single courageous state may, if its citizens choose, serve as a laboratory and try novel social and economic experiments without risk to the rest of the country' (Card and Krueger, 1995). It is much less easy in Europe, where minimum wages are generally a national minimum.

But there are other control groups to use. For example, a rise in the minimum wage should have more effect on the employment of low-wage groups than highwage groups: what might be called the 'differential' impact approach. The groups might be regions (as in Card (1992a, 1992b) and the studies of France and Spain below), firms (as in Card and Krueger, 1994), individuals (as in Currie and Fallick, 1994), segments of the labour market as defined by age and education (as in the study of France below), industries (as in the study of the abolition of minimum wages in the UK below) or occupations (as in the study of the Netherlands below).

This approach has intuitive appeal, but again a number of weaknesses. First, it is only as good as the control group used. For example, Card and Krueger (1995) criticize Currie and Fallick for ascribing all the difference in the risk of job loss between low- and high-wage individuals to the effect of the minimum wage. Much the same relationship between risk of job loss and wages exists for workers not covered by the minimum wage. As we show in the Technical Appendix, there are potential dangers in using high-wage agents as control groups for low-wage agents when we have no explanation as to why a high wage was chosen in the furst place. Second, the approach 
is most likely to produce reliable and precise results when there is a large rise in the minimum wage, so that differences in the experience of the treatment and control groups are most plausibly due to the effect of the minimum wage. Again the USA is a more fruitful field for this approach because it has infrequent but large changes in minimum wages. European countries in which minimum wages are upgraded annually in line with average wages offer fewer examples of large changes in minimum wages. ${ }^{5}$ Third, this approach typically compares employment shortly before and shortly after changes in the minimum wages. This may not be such a problem in the USA, where labour turnover rates are high and firing costs are low; but it might be more of a problem in Europe, where lower turnover rates and firing costs mean that employers are more likely to adjust employment in advance of predictable minimum wage changes, and the adjustment process may be more drawn out. Looking at

3 employment changes over a longer period reduces this problem, but makes it more difficult to ascribe observed changes to changes only in minimum wages.

A third approach (to which the OECD fobs Study. (OECD, 1994) devotes most discussion) was developed by Meyer and Wise (1983a, 1983b) and subsequently used by, among others, Albaek and Madsen (1987, 1989) and van Soest (1989, 1994). It attempts to infer the employment effect of minimum wages using only data on the cross-sectional distribution of wages, claiming to estimate the effect of minimum wages without having any variation in the minimum at all. But some very strong assumptions are necessary to do this: a particular distribution of wages in the absence of the minimum (e.g. log-normal), and an assumption that workers earning above a certain level are unaffected by the minimum. One then estimates the parameters of the wage distribution from those earring above the minimum, infers how many people should be earning at or below the minimum, and compares this figure with the number of people actually there. The theoretical foundation for this approach is very weak (it is totally inappropriate in the model of the Technical Appendix) and there is a serious danger that the results are very sensitive to the precise assumptions made about the distribution of wages and the way it is affected by minimum wages. For the UK, Dickens et al. (1994b) conclude that these problems are so serious as to make this approach unusable.

\subsection{Minimum wages are inappropriate for small open economies}

Many discussions in Europe emphasize the need to encourage wage moderation to preserve international competitiveness. It is argued that a single economy that raises its minimum wage will raise its wages relative to competitors with adverse effects on traded goods industries.

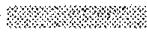

'We study some of these large changes below. Others that we discovered but have not examined are Greece in 1982 , Denmark in 1977 and Switzerland in 1995. 
Table 2. Distribution of workers by sector ( $\%$ of workers)

\begin{tabular}{|c|c|c|c|c|c|c|c|c|c|c|c|}
\hline Country & $\begin{array}{c}\text { Category of } \\
\text { worker }\end{array}$ & Agriculture & Mining & $\begin{array}{c}\text { Clothing } \\
\text { and leather }\end{array}$ & $\begin{array}{c}\text { Other } \\
\text { manufacturing }\end{array}$ & $\begin{array}{l}\text { Electricily, } \\
\text { gas, water }\end{array}$ & Construction & $\begin{array}{l}\text { Trade, } \\
\text { restaurants, } \\
\text { hotels }\end{array}$ & Transport & $\begin{array}{l}\text { Finance, } \\
\text { insurance, } \\
\text { etc. }\end{array}$ & $\begin{array}{l}\text { Personal } \\
\text { services }\end{array}$ \\
\hline $\begin{array}{l}\text { France } \\
(1989)\end{array}$ & $\begin{array}{c}\text { All } \\
\text { Min. wage }\end{array}$ & & $\begin{array}{l}0.4 \\
0.0\end{array}$ & $\begin{array}{l}2.1 \\
6.2\end{array}$ & $\begin{array}{l}20.4 \\
10.3\end{array}$ & $\begin{array}{l}1.0 \\
0.0\end{array}$ & $\begin{array}{l}7.7 \\
5.2\end{array}$ & $\begin{array}{l}18.1 \\
25.7\end{array}$ & $\begin{array}{l}6.8 \\
2.9\end{array}$ & $\begin{array}{c}10.1 \\
4.12\end{array}$ & $\begin{array}{l}33.2 \\
45.5\end{array}$ \\
\hline $\begin{array}{l}\text { Netherlands } \\
(1993)\end{array}$ & $\begin{array}{c}\text { All } \\
\text { Min. wage }\end{array}$ & $\begin{array}{l}4.8 \\
1.7\end{array}$ & $\begin{array}{l}0.2 \\
0.0\end{array}$ & $\begin{array}{r}22.8 \\
8.3\end{array}$ & & $\begin{array}{l}0.9 \\
0.1\end{array}$ & $\begin{array}{l}9.4 \\
2.4\end{array}$ & $\begin{array}{l}16.1 \\
43.9\end{array}$ & $\begin{array}{l}8.1 \\
2.8\end{array}$ & $\begin{array}{l}11.0 \\
19.5\end{array}$ & $\begin{array}{l}26.5 \\
21.4\end{array}$ \\
\hline $\begin{array}{l}\text { Portugal } \\
\text { (1989) }\end{array}$ & $\begin{array}{c}\text { All } \\
\text { Min. wage }\end{array}$ & & $\begin{array}{l}0.8 \\
0.4\end{array}$ & $\begin{array}{l}5.5 \\
4.2\end{array}$ & $\begin{array}{r}23.4 \\
213.0\end{array}$ & $\begin{array}{l}1.2 \\
0.0\end{array}$ & $\begin{array}{l}9.8 \\
7.0\end{array}$ & $\begin{array}{l}19.4 \\
26.5\end{array}$ & $\begin{array}{l}58 \\
0.9\end{array}$ & $\begin{array}{l}5.4 \\
1.1\end{array}$ & $\begin{array}{l}28.7 \\
38.6\end{array}$ \\
\hline $\begin{array}{l}\text { Spain } \\
\text { (1994) }\end{array}$ & $\begin{array}{c}\text { All } \\
\text { Min. wage }\end{array}$ & & & $\begin{array}{r}21.3 \\
9.8\end{array}$ & & $\begin{array}{l}1.4 \\
0.1\end{array}$ & $\begin{array}{l}9.0 \\
8.8\end{array}$ & $\begin{array}{l}67.3 \\
81.3\end{array}$ & & & \\
\hline $\begin{array}{l}\text { United } \\
\text { Kingdom } \\
(1994)\end{array}$ & $\begin{array}{c}\text { All } \\
\text { Min. wage }\end{array}$ & $\begin{array}{l}1.1 \\
2.1\end{array}$ & $\begin{array}{l}0.4 \\
0.1\end{array}$ & $\begin{array}{r}2.0 \\
41.0\end{array}$ & $\begin{array}{r}16.5 \\
6.8\end{array}$ & $\begin{array}{l}0.9 \\
0.1\end{array}$ & $\begin{array}{l}4.6 \\
1.9\end{array}$ & $\begin{array}{l}20.4 \\
41.4\end{array}$ & $\begin{array}{l}6.7 \\
4.3\end{array}$ & $\begin{array}{r}13.2 \\
9.6\end{array}$ & $\begin{array}{l}32.2 \\
25.5\end{array}$ \\
\hline
\end{tabular}

Notes: In the UK, minimum wage workers are defined as those with an hourly wage below 63.50 in Aprit 1995 prices. In the Netherlands, the minimum wage is defined a those paid within $5 \%$ of the statutory minimum. For Spain, Portugal and France, data are official estimates.

Sources: ILO Yearbook of Labour Statistics; Combault (1995); supplemented by data for particular countries (details available from the authors). 
This argument makes sense if the labour market is competitive (as in Figure 3a), for then a given rise in the minimum wage will have a larger negative effect on employment the more elastic (flatter) is the labour demand curve, as is most likely with severe international competition. But we also saw that the employment-raising potential of the minimum wage in monopsonistic labour markets is larger if the labour demand curve becomes more elastic. With a large international market, increased employment and increased output can be achieved with little reduction in price. The marginal revenue product of labour does not fall as fast as employment rises. Again, the effect of minimum wages is very different in competitive and monopsonistic labour markets.

Another important point is that the low paid in European countries are typically not concentrated in traded goods industries. Table 2 presents information on minimum

\$ wage workers by sector for our four countries (plus Portugal, a lower-wage country) and (as a comparison) the sectoral distribution of employment for all workers. Lowwage workers are generally underrepresented in manufacturing: typically clothing and leather (and also furniture making) is the only manufacturing sector with many lowpaid workers. The comparative advantage of developed economies tends to be in relatively skill-intensive industries. However, the importance of tourism, which may be price sensitive, may mean that the wages of workers in many service industries are. important for the competitive position of the Spanish and Portuguese economies.

\subsection{Lower labour taxes or subsidies are a better way to help the low paid}

One of the main aims of the minimum wage is to improve the living standards of the low paid. The minimum wage is not the only way in which this might be done. Those who want to argue that a minimum wage is desirable need to demonstrate that it is a more effective policy tool than alternatives. Perhaps the most prominent alternative is to reduce the taxes or even subsidize the employment of the low paid.

A lower tax rate on labour will lead to a rise in employment and living standards for the affected workers in both competitive and monopsonistic labour markets. For a given producer wage, labour supply increases. But reduced labour taxes will reduce tax revenue, so they must be paid for in some way. The usual proposal is that the taxes on the low paid should be reduced and those on the higher paid increased: a more progressive tax system. In a competitive labour market, this might be a better policy than a minimum wage because it raises the living standards of the low paid while raising their employment at the same time ${ }^{6}$. The reason for the difference is that the subsidy received by the low paid is paid by different groups: the employers of the low paid in the case of a minimum wage and higher-paid workers in the case of a reduced tax burden.

\section{\%............}

'This policy might still reduce incentives to invest in the acquisicion of skills 
But matters differ if the labour market is monopsonistic. Making the tax system more progressive makes the effective supply of labour facing the monopsonistic firm more inelastic (steeper): it would change from $N S_{1}$ to $\mathcal{N S}_{2}$ in Figure 4 . This raises the marginal cost of labour from $M C L_{1}$ to $M C L_{2}$ so that the wage paid by the employer and employment fall. Effectively, one is providing subsidies for employers to cut wages. This effect can be so large that the living standards of the low paid actually fall when their labour is subsidized (an effect that is akin to the overshifting of taxes that can occur in oligopolistic product markets). The minimum wage in this case is a much better policy because making the labour supply curve facing the employer flatter is a move towards efficiency. Again, policy recommendations depend on one's view of the way in which labour markets work.

\subsection{Most minimum wage workers are young}

A high proportion of both research and policy discussion on the effects of the minimum wage focuses on the young. From this, one might conclude that young workers are the main group affected by the minimum wage. But while it is certainly true that young workers are more likely to be low paid than the average worker, it is not necessarily true that young workers make up the bulk of the low paid. Young workers typically make up a small proportion of the total workforce. Table 3 presents some information for our four countries on the proportion of low-paid workers who fall into a number of categories. Young workers used to be a higher proportion of the low paid, but their importance has declined with rises in school enrolment and women's labour market participation. For example, in the UK, the proportion of workers in the bottom decile of the hourly wage distribution who are teenagers fell from $40 \%$ in the mid-1970s to $18 \%$ in the early 1990 s. The focus on the effect of minimum wages on the youth labour market leads to a misleading impression of the effect on the labour market as a whole. It may be, for example, that the minimum wage does reduce employment for young workers, but that it increases employment of women and that the latter effect dominates (as suggested

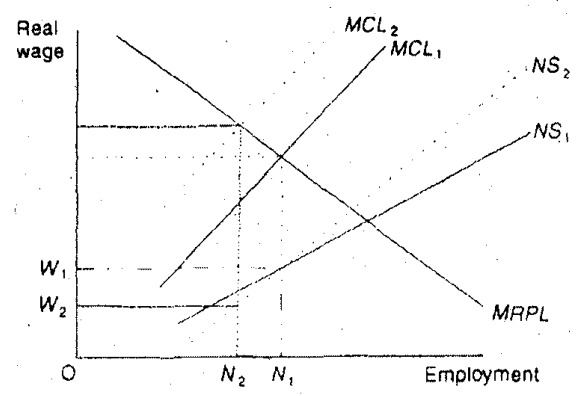

Figure 4, Labour subsidies for the low paid in a monopsonistic labour market 
Table 3. Characteristics of the low paid

\begin{tabular}{lcccc}
\hline & $\begin{array}{c}\text { France } \\
(1990)\end{array}$ & $\begin{array}{c}\text { Netheriands } \\
(1985)\end{array}$ & $\begin{array}{c}\text { Spain } \\
(1990)\end{array}$ & $\begin{array}{c}\text { United Kingdom } \\
(1994)\end{array}$ \\
\hline Proportion female & 0.54 & 0.81 & 0.58 & 0.66 \\
Proportion age <21 & 0.09 & 0.01 & 0.41 & 0.29 \\
Proportion part öme & 0.11 & 0.71 & 0.37 & 0.52 \\
\hline
\end{tabular}

Sources: French computations from Enguéte Enpior, Netherlands computations from 1985 Wage Survey, Spanish compucations from Vaidés (1992), Labour Force Survgy and Tax Rebuns, UK computaions from Labour Force Surney.

below in evidence for Spain). Unfortunately, some of this paper only reinforces this emphasis on the youth labour market, since the obsession with the youth labour market means that most of the policy changes have concerned youth minimum wages and economists need such changes to study the effects of minimum wages. We know very little about the effect of minimum wages on women's employment although there is evidence from some countries that quite large increases in women's pay achieved through equal pay legislation had no noticeable adverse effects on their employment (see Manning (1996) for a study of the UK Equal Pay Act). It is possible that the effect of minimum wages might be similar. More research is needed.

\subsection{Most minimum wage workers are not in poor households so a minimum wage does little to alleviate poverty}

There is an important element of truth in this. The main cause of poverty in most European countries is unemployment, and the minimum wage does nothing to raise the living standards of those households in which nobody is in work. But it is unreasonable to expect the minimum wage to have such an effect. It might be more reasonable to focus on those households which do have someone in work.

Table 4 presents information on the position of minimum wage workers in the household income distribution for the countries that we study. For every individual in a household with someone in work, we assign a level of equivalized income based on total household income adjusted for the number of adults and children in that household. We then order individuals by this equivalized income level and ask what proportion of workers in each decile are minimum wage workers, yielding a picture of where minimum wage workers are in the household income distribution.

As we move up the household earnings distribution, the proportion of minimum wage workers falls. Low-paid workers do tend to be in poorer households. However, there are two ways in which the minimum wage may not be a very effective antipoverty tool. First, low-paid workers may not all be in poor households (although we know little about the distribution of income within households). Second, many poor households may contain no minimum wage worker. In all our countries, the picture 
Table 4. The relationship between mimirnean wages and income distribution

\begin{tabular}{|c|c|c|c|c|c|c|c|c|}
\hline \multirow[t]{2}{*}{ Decile } & \multicolumn{2}{|c|}{ France } & \multicolumn{2}{|c|}{ Netherlands } & \multicolumn{2}{|c|}{ Spain } & \multicolumn{2}{|c|}{ United Kingdom } \\
\hline & $\begin{array}{c}\% \\
\text { affected }\end{array}$ & $\begin{array}{l}\% \text { of } \\
\text { affected }\end{array}$ & $\begin{array}{c}\% \\
\text { affected }\end{array}$ & $\begin{array}{l}\% \text { of } \\
\text { affected }\end{array}$ & $\begin{array}{c}\% \\
\text { affected }\end{array}$ & $\begin{array}{c}\% \text { of } \\
\text { affected }\end{array}$ & $\begin{array}{c}\% \\
\text { affected }\end{array}$ & $\begin{array}{l}\% \text { of } \\
\text { affected }\end{array}$ \\
\hline All & 7.2 & 100.0 & 11.5 & 100.0 & 6.6 & 100.0 & 14.5 & 100.0 \\
\hline 1 & 10.1 & 13.2 & 35.0 & 30.4 & 23.5 & 35.5 & 41.7 & 28.7 \\
\hline 2 & 11.3 & 15.8 & 21.0 & 18.2 & 12.2 & 18.4 & 19.1 & 13.2 \\
\hline 3 & 13.1 & 17.7 & 24.0 & 20.9 & 9.6 & 14.5 & 18.2 & 12.5 \\
\hline 4 & 8.4 & 11.4 & 16.0 & 13.9 & 7.4 & 11.2 & 12.2 & 8.4 \\
\hline 5 & 6.6 & 9.1 & 8.0 & 6.9 & 6.2 & 9.4 & 11.8 & 8.1 \\
\hline 6 & 7.4 & 10.7 & 5.0 & 4.3 & 3.2 & 4.8 & 10.3 & 7.1 \\
\hline 7 & 7.1 & 9.8 & 2.0 & 1.7 & 2.1 & 3.2 & 12.1 & 8.3 \\
\hline 8 & 5.1 & 7.4 & 2.0 & 1.7 & 1.3 & 2.0 & 8.0 & 5.5 \\
\hline 9 & 2.2 & 4.1 & 1.0 & 0.9 & 0.6 & 0.9 & 5.4 & 3.7 \\
\hline 10 & 0.6 & 0.8 & 1.0 & 0.9 & 0.1 & 0.2 & 6.9 & 4.7 \\
\hline
\end{tabular}

Noves: For each country, the first column is the proportion of individuals in each decile of the equivalized household income distribution who are minimum wage eamers; the second column is the fraction of individuals who are affected by the minimum wage who are in each decile. For the Netherlands it is the adult rate that is used for all workers, which is why the incidence is high. Households without any worker are excluded from these computations. These figures make no allowance for taxes and benefits that may be very important in practice. See Sutheriand (1995) for an analysis of the UK, Nolan (1993) for Ireland, for analyses including the tax/benefit system.

Sources: Spain and UK as in Table 3; France from the Enquête Actifs Financiers (1990); the Netherlands from a micro model used by the Ministry of Social Affairs.

is similar: minimum wage workers tend to be in low-income households, but a considerable proportion are quite a long way up the household income distribution.

\section{THE EFFECT OF MINIMUM WAGES ON EMPLOYMENT}

In this section we present more detailed studies of four European countries. In each we provide an account of particular episodes, but we are not necessarily in a position to provide an overview of the effect of the minimum wage system as a whole because most of our countries have essentially had the same system throughout our study period.

\subsection{France}

France first instituted minimum wages in 1950, when a law was passed establishing the SMIG (salaire minimum interprofessionel garanti, or guaranteed minimum earnings). The SMIG was raised in line with prices when the inflation rate exceeded $5 \%$ per year (reduced to $2 \%$ per year in 1957), but was not indexed to earnings growth. The consequence (see Figure 1) was that the Kaitz index fell from a very high level in 1950 to a very low level by the late 1960s. A major revision of the minimum wage law took place in 1970, converting the SMIG to the SMIC (salaire minimum interprofessionel de croissance, or minimum wage for growth), revised each July to 
increase in line with prices and by no less than $50 \%$ of the amount by which the real TSH (taux de salaire horaire oucrier, or hourly blue-collar wage) increased in the previous year. Neither minimum wage law ruled out increases above the required minima; nor did they prevent the government from increasing the minimum at dates other than 1 July. The largest discretionary increases in minimum wages were in 1968, the early 1970s and (more modestly) the early 1980s (see Figure 1). From 1988 to 1993 the SMIC evolved at the same rate as the TSH. In 1993 and 1994 the SMIC increased by the bare minimum. Newly elected President Chirac raised the SMIC by $4 \%$ in July 1995.

. The SMIC is not the only form of minimum wages in France. French law allows minimum wages to be set by collective bargaining agreements that apply only if they exceed the statutory minimum wage. At the beginning of the 1980s, many of the minimum rates in these agreements were above the SMIC, but since then sectoral minima have grown less rapidly than the SMIC: by $199060 \%$ of sectoral agreements had' some point on their pay scales below the SMIC, so one reason why the proportion of workers paid the SMIC was higher in the 1980s (see Figure 2) may be a reduction in sectoral minima rather than a more generous SMIC.

There have also been important changes in recent years in the operation of the SMIC in response to growing concern about the possible adverse effect of minimum wages on the employment of vulnerable groups: notably those aged less than 25 , but also some for the long-term unemployed. These schemes offer subsidies to employers (often in the form of exemptions from payroll taxes) and also often reduce the wage received by the worker. For example, the apprenticeship and qualification contracts (the largest in terms of numbers on the schemes) allow a 16-year-old to be paid 25\% of the SMIC, rising to $78 \%$ for a $22-5$-year-old in the final year of the contract. The growth in the number of workers on these schemes has been dramatic, from about 8000 in 1976 to about 900000 in 1993 with the largest rise after 1986 (Gelot, 1995). The effect on wages paid is noticeable. The proportion of workers paid below the SMIC rose from $1 \%$ in 1981 to $4 \%$ in 1989. And the OECD reported that the average wage for French teenagers in 1987 was actually below the SMIC. This should be taken not as evidence that the SMIC is set at a very high rate, but as an indication that the $\mathrm{SMIC}$ is not the effective minimum wage for these workers.

Let us now consider evidence of the SMIC's effect on employment and unemployment in France. Bazen and Martin (1991) used a time-series approach to conclude that the minimum wage had a modest adverse effect on youth employment, but their methodology assumes both the validity of the competitive model and that minimum wages can affect employment only through an effect on the average wage. However, they concluded that their estimates might not be robust, a conclusion also reached by Benhayoun (1994) in his study of the effect of the minimum wage on youth employment. Abowd et al. (1995) compare France and the USA, claiming to find evidence of modest employment reductions associated with the SMIC. What can we say about the employment effects? 
A commonly heard argument is that the SMIC was raised substantially in the early part of the 1980s and is important in explaining high and persistent unemployment in France. Does the experience of the 1980s support this view? Both the Kaitz index and the estimates of the spike (see Figures 1 and 2) suggest that the SMIC became more important from 1981 to 1985 (although the size of the increase was quite modest), since when its importance has declined slightly. In looking for employment effects of the SMIC in the 1980s, we therefore divided the 1980s into two periods: 1981-5 when Mitterrand (as president) raised the SMIC relative to average earnings, and 1985-9 when Chirac (as prime minister) did not. Our intention is to estimate the effect of the SMIC by comparing the labour market fortunes of parts of the labour market strongly influenced by the SMIC with those parts that are not. So we divide the labour market into six age groups, eight education groups and the two sexes, making 96 segments in total. As our measure of the impact of the SMIC on each segment, we use the fraction of workers paid a wage near the SMIC in 1985'. As we are also interested in the effect of the schemes, we also compute the proportion of workers in each segment paid below the SMIC in 1985, which we expect to pick up the groups particularly affected by the schemes. We then look at how labour market outcomes are related to these two variables. The results are presented in Table 5, with separate estimates for men and women.

The first row of each part of the table shows the results of a regression of the change in the real log hourly wage on the proportion of workers paid the SMIC and the proportion below it. This regression was run for the whole period and for $1981-5$ and 1985-9 separately. From column (3) one can see that real wage growth in the period $1981-5$ is positively related to the proportion of workers paid close to the SMIC, but that the estimated coefficient is not significantly different from zero. There is little evidence that the rise in the minimum wage under Mitterrand led to larger wage increases for low-paid groups. One could argue that the relative wages of the lower paid would have fallen further in the absence of the rise in the minimum. If so, we would expect to see a very strong fall in the relative wages of the low paid from 1986 to 1989 , but the coefficient in column (5) shows that this is not the case. The coefficient on the proportion of workers paid below the SMIC is also inconsistent with what one would expect, with stronger negative wage growth in 1981-5 (when the schemes were relatively small scale) than in 1986-9 (when they were on a much larger scale). So the changes in the structure of wages do not provide much evidence that the Mitterrand period was one in which minimum wages were increased very strongly, while the Chirac period was one in which minimum wages did not increase. This is consistent with other studies documenting

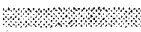

"As in Figure 2. 'near the SMIC' is defined by having monthly earnings in the band which includes the SMIC multiplied by usual montlly hours. We compute the proportions using 1985 data, when schemes had become large and data more reliable. 
Table 5. Changes in the French labour market, 1981-9

\begin{tabular}{|c|c|c|c|c|c|c|}
\hline \multirow[t]{2}{*}{ Change in: } & \multicolumn{2}{|c|}{$1981-9$} & \multicolumn{2}{|c|}{$1981-5$} & \multicolumn{2}{|c|}{$1985-9$} \\
\hline & $\begin{array}{c}\text { Proportion } \\
\text { near } \\
\text { SMIC } \\
\text { (I) }\end{array}$ & $\begin{array}{c}\text { Proportion } \\
\text { below } \\
\text { SMIC } \\
(2)\end{array}$ & $\begin{array}{l}\text { Proportion } \\
\text { near } \\
\text { SMIC } \\
\text { (3) }\end{array}$ & $\begin{array}{l}\text { Proportion } \\
\text { below } \\
\text { SMIC } \\
(4)\end{array}$ & $\begin{array}{l}\text { Proportion } \\
\text { near } \\
\text { SMIC } \\
\text { (5) }\end{array}$ & $\begin{array}{c}\text { Proportion } \\
\text { below } \\
\text { SMIC } \\
(6)\end{array}$ \\
\hline \multicolumn{7}{|l|}{ Men } \\
\hline Log hourly wage & $\begin{array}{c}0.89 \\
(1.66)\end{array}$ & $\begin{array}{l}-2.08 \\
(1.94)\end{array}$ & $\begin{array}{c}0.36 \\
(1.09)\end{array}$ & $\begin{array}{c}-1.17 \\
(1.78)\end{array}$ & $\begin{array}{c}0.33 \\
(0.90)\end{array}$ & $\begin{array}{c}-0.15 \\
(0.21)\end{array}$ \\
\hline $\begin{array}{l}\text { Proportion } \\
\text { near SMIC }\end{array}$ & $\begin{array}{c}0.96 \\
(1.87)\end{array}$ & $\begin{array}{c}2.74 \\
(2.07)\end{array}$ & $\begin{array}{c}1.26 \\
(3.38)\end{array}$ & $\begin{array}{l}3.08 \\
(3.18)\end{array}$ & $\begin{array}{c}0.32 \\
(0.11)\end{array}$ & $\begin{array}{c}-0.43 \\
(1.89)\end{array}$ \\
\hline $\begin{array}{l}\text { Proportion } \\
\text { below SMIC }\end{array}$ & $\begin{array}{c}1.01 \\
(5.83)\end{array}$ & $\begin{array}{c}-0.64 \\
(1.42)\end{array}$ & $\begin{array}{r}1.33 \\
(7.81)\end{array}$ & $\begin{array}{c}0.13 \\
(0.29)\end{array}$ & $\begin{array}{c}0.24 \\
(3.61)\end{array}$ & $\begin{array}{c}-0.48 \\
(3.56)\end{array}$ \\
\hline $\begin{array}{l}\text { Employment } \\
\text { rate }\end{array}$ & $\begin{array}{c}-0.47 \\
(1.32)\end{array}$ & $\begin{array}{c}0.93 \\
(1.32)\end{array}$ & $\begin{array}{r}-0.12 \\
(0.45)\end{array}$ & $\begin{array}{c}-0.62 \\
(1.13)\end{array}$ & $\begin{array}{r}-0.06 \\
(0.25)\end{array}$ & $\begin{array}{c}0.90 \\
(2.00)\end{array}$ \\
\hline $\begin{array}{l}\text { Unemployment } \\
\text { rate }\end{array}$ & $\begin{array}{c}0.89 \\
(3.94)\end{array}$ & $\begin{array}{r}-1.63 \\
(3.50)\end{array}$ & $\begin{array}{c}0.28 \\
(2.01)\end{array}$ & $\begin{array}{c}0.68 \\
(2.45)\end{array}$ & $\begin{array}{c}0.42 \\
(2.04)\end{array}$ & $\begin{array}{r}-1,78 \\
(4.26)\end{array}$ \\
\hline \multicolumn{7}{|l|}{ Women } \\
\hline Log hourly wage & $\begin{array}{r}0.43 \\
(1.09)\end{array}$ & $\begin{array}{c}-1.04 \\
(1.43)\end{array}$ & $\begin{array}{c}0.18 \\
(0.71)\end{array}$ & $\begin{array}{c}-0.38 \\
(0.81)\end{array}$ & $\begin{array}{c}0.07 \\
(0.34)\end{array}$ & $\begin{array}{c}0.01 \\
(0.03)\end{array}$ \\
\hline $\begin{array}{l}\text { Proportion } \\
\text { near SMIC }\end{array}$ & $\begin{array}{r}0.49 \\
(1.73)\end{array}$ & $\begin{array}{c}-0.31 \\
(0.26)\end{array}$ & $\begin{array}{c}0.49 \\
(1.83)\end{array}$ & $\begin{array}{c}0.12 \\
(0.11)\end{array}$ & $\begin{array}{c}0.39 \\
(4.46)\end{array}$ & $\begin{array}{r}-0.91 \\
(5.70)\end{array}$ \\
\hline $\begin{array}{l}\text { Proportion } \\
\text { below SMIC }\end{array}$ & $\begin{array}{l}0.71 \\
(4.28)\end{array}$ & $\begin{array}{r}-1.30 \\
(1.90)\end{array}$ & $\begin{array}{c}0.76 \\
(4.72)\end{array}$ & $\begin{array}{c}-1.22 \\
(1.86)\end{array}$ & $\begin{array}{l}0.24 \\
(0.06)\end{array}$ & $\begin{array}{l}-0.34 \\
(3.30)\end{array}$ \\
\hline $\begin{array}{l}\text { Employment } \\
\text { rate }\end{array}$ & $\begin{array}{l}-0.52 \\
(2.04)\end{array}$ & $\begin{array}{c}0.79 \\
(1.69)\end{array}$ & $\begin{array}{c}0.44 \\
(2.1 !)\end{array}$ & $\begin{array}{c}-1.10 \\
(2.86)\end{array}$ & $\begin{array}{l}-0.61 \\
(2.94)\end{array}$ & $\begin{array}{c}1.15 \\
(3.01)\end{array}$ \\
\hline $\begin{array}{l}\text { Unemployment } \\
\text { rate }\end{array}$ & $\begin{array}{c}1.27 \\
(6.54)\end{array}$ & $\begin{array}{l}-1.54 \\
(4.29)\end{array}$ & $\begin{array}{l}0.00 \\
(0.05)\end{array}$ & $\begin{array}{c}0.97 \\
(3.41)\end{array}$ & $\begin{array}{c}0.85 \\
(4.89)\end{array}$ & $\begin{array}{l}-1.51 \\
(4.75)\end{array}$ \\
\hline
\end{tabular}

Notes: The numbers reported ( $t$-statiscics in parentheses) are coefficients from a regression of the variable in the lefi column on the proportion of workers paid near the SMIC and the proportion paid below it in 1985; cells are across 8 education groups and 6 age groups. Each regression thus has 48 observations. Data from the Erquête Emploi.

the stability of the French wage structure in this period (Card et al., 1995): one possible explanation is the declining importance of the sectoral minima in the 1980s.

The second and third rows present estimates of regressions in which the change in the proportion paid near the SMIC (the second row) and below the SMIC (the third row) are regressed on the proportion paid near and below the SMIC in 1985. For men the second row supports the hypothesis that the growth in the proportion paid near the SMIC grew more rapidly in $1981-5$ than in 1985-9; but this is not true for women. There is also little evidence here for the view that the proportion of workers paid below the SMIC grew more strongly in the second period than in the first period. Again these regressions do not provide strong support for the perception of France in the 1980s as a country in which the minimum wage was being strengthened very rapidly.

Now let us turn to employment outcomes. The fourth and fifth rows of Table 5 
present regressions similar to those presented above, but with employment rates (the fourth row) and unemployment rates (the fifth row) as the dependent variable. The employment and unemployment effects almost always go in opposite directions; our discussion is confined to unemployment effects. For men there is evidence that the rise in the unemployment rate in the Mitterrand period was larger for groups with a high proportion of workers paid at or below the SMIC; in the Chirac period, the change in the unemployment rate was positively related to the proportion of workers paid near the SMIC, but negatively related to the proportion paid below the SMIC. These estimates are consistent with the view that the SMIC was responsible for some of the rise in unemployment in the 1980s, an effect that was mitigated in the second half of the decade by the expansion of the schemes allowing workers to be paid below the SMIC.

Before accepting this conclusion, one must recognize that these results are consistent with an alternative hypothesis. The years $1981-5$ were a recession and the years 1985-9 were a weak recovery. The unemployment rates of low-paid workers, particularly the young, rise more in recession but fall more in booms. As low-paid workers are more likely than others to be paid the SMIC, the results in Table 5 may be the normal response to recession and recovery.

The results reported in Table 5 are not robust to the inclusion of dummy variables for the age and education of the workers. The behaviour of wages is arguably more consistent with this story than with the minimum wage story, since the young are the main group of workers paid below the SMIC and the wage growth of workers paid below the SMIC was particularly strong in the period 1986-9. There seems to be no way, using these data, to distinguish the two hypotheses using information from the 1980 s alone. It is also possible that the employment and unemployment effects of the minimum are understated: adjustment of employment is very slow in France (because of high firing costs), which, combined with the fact that minimum wage increases are largely predictable, means it is likely that some employment adjustment takes place before rises in the minimum wage.

The main problem in interpreting the experiences of the 1980 s arises because changes in the minimum wage in that period were relatively modest (much smaller than the episodic large increases in the US federal minimum) and because the time periods we consider are relatively short. But looking at Figures 1 and 2, we can see that there had been much bigger changes in the minimum wage in 1968 and 1973-4. We might hope that there is a better chance of estimating the minimum wage effects from these episodes. Regressions similar to those reported above indicate that the segments of the labour market with large proportions of workers near the SMIC had larger rises in their unemployment rates in the 1970s, but the same problem of interpretation arises because this was a period of a general rise in unemployment. So we take a different approach here. Because the SMIC is a single national minimum and there is considerable regional wage dispersion, we expect big rises in the SMIC to have larger effects on the economy in low-wage regions. This is 
the methodology used by Card (1992a) in his study of the rise in the federal minimum wage in the USA. For this purpose we use data on wages and employment by département for the period 1967-92 (the beginning of the period marks the end of regional differences in minimum wages).

In a year with a large rise in the minimum wage, we expect larger wage rises in the regions which initially had very low wages and hence a reduction in the dispersion of wages across regions. There is evidence that increases in the SMIC have led to reductions in regional wage inequality. Figure 5 plots the change over time in the log of the Kaitz index and the variance across départements of log earnings for male blue-collar workers for the period 1967-92. The sharp decline in regional wage dispersion until the early 1980 s is very clear, since when it has been approximately constant. This is the mirror image of the behaviour of the Kaitz index, which rose until the early 1980s and then was approximately constant. The relationship appears to be strong even when one looks at correlations of the change in the variance with the change in the log Kaitz index (the estimate of the slope has a $t$ statistic of 4.9).

The same information is presented differently in Table 6. In the first column we present the resuits of a regression of the change in wages from the late 1960s to the mid-1980s (the period of the rise in the Kaitz index) on the initial level of wages. As can be seen, wage growth was much faster in regions that initially had low wages,

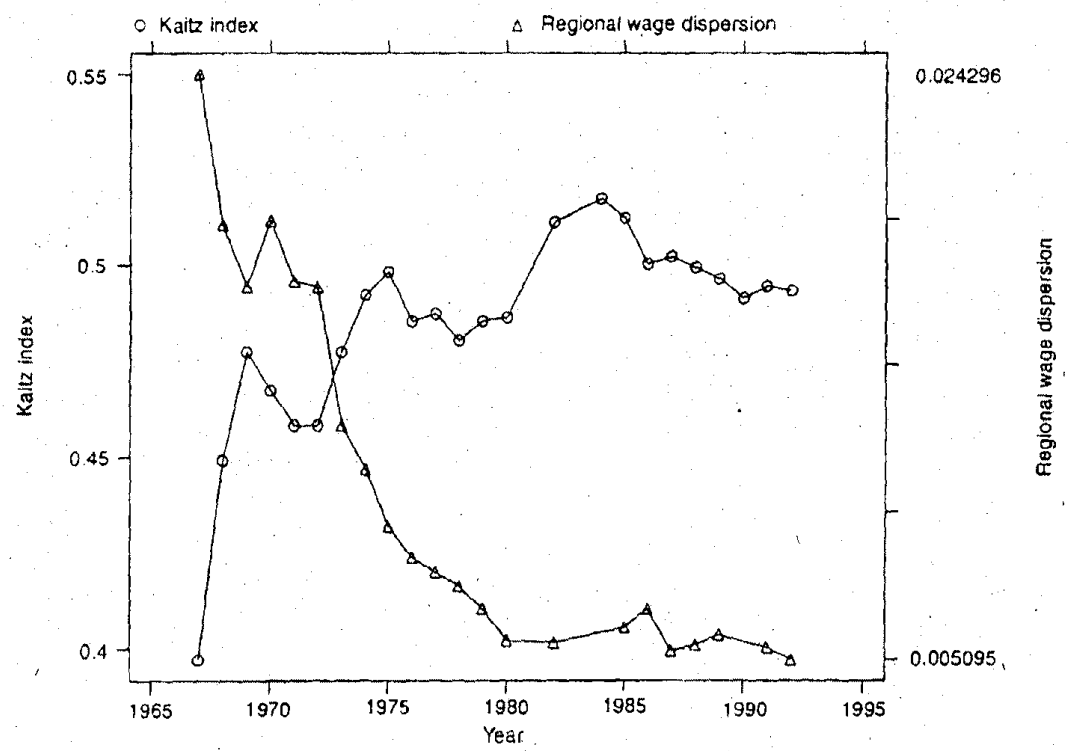

Figure 5. Regional wage dispersion and the Kaitz index in France, 1967-92

Notes: The right-hand axis is the variance in the log of hourly blue-collar wages across 95 depertements. The left-hand axis is the Kaicz index as used in Figure l. 
Table 6. Wage ard empioyment growth across French regions, 1967-92

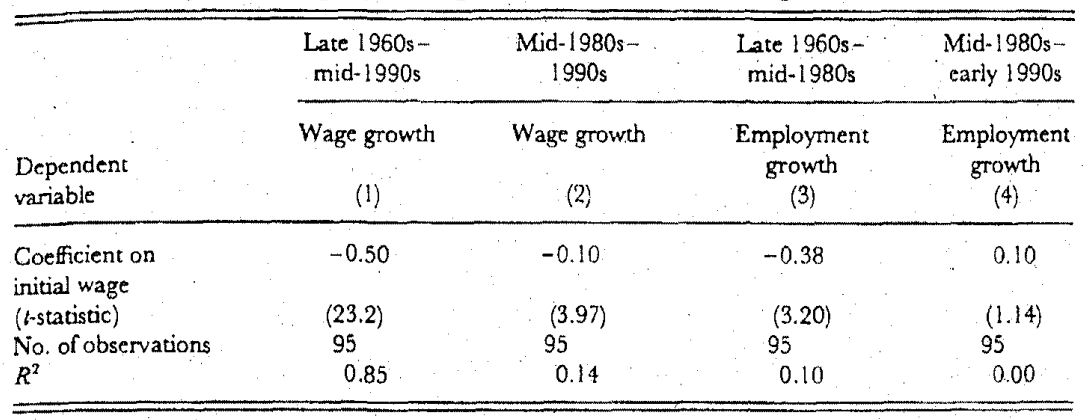

Notes. We also estimated regressions with extra controls: the average share of employment in agriculture, manufacturing, services and construction, for each departement over the 1980 s (the only period for which we have such). The results on wages were identical. The results for employment differ slightly, with the coefficient on the initial wage now insignificantly different from zero in the first period (but still negative) and significantly positive in the second period. High-wage regions still did relatively worse in the period when the minimum wage increased.

Source: Data from the annual 'Les Salaires dans l'industric, le commerce et les services', based on the Declaration Annuelle de Salaires.

confirming that this was a period of strongly declining regional wage inequality. We also ran the same regression using the change in wages from the mid-1980s to the early 1990s, a period in which the change in the Kaitz index was much more modest. There is still a relationship between wage growth and initial wages, but it is much weaker. This is consistent with the rise in the SMIC in the first period leading to a reduction in regional wage inequality.

Now consider the effects on employment growth. If minimum wages reduce employment, we expect a positive relationship between employment growth and the initial level of wages when minimum wages were raised strongly relative; if minimum wages raise employment, we expect a negative relationship. Column (3) presents the results of a regression of the change in employment from the late 1960 s to the mid1980s on the initial level of wages. Employment growth is significantly higher in departements that initially had low wages. This is not what we would expect if minimurn wages were destroying jobs in this period: this evidence suggests, if anything, that the rise in the SMIC over this period actually led to higher employ* ment. A similar regression run over the period from the mid-1980s to the early 1990 s (column (4)) shows no such rclationship in this period, suggesting that this is not because of some long-term trend. So low-wage regions did relatively well in the period 1967-85, a period when minimum wages were raised very dramatically.

In conclusion, French evidence suggests that the substantial rise in the SMIC to the mid-1980s had no adverse effect on employment. One can make a case that, by the mid-1980s, the SMIC had reached levels that were causing employment losses, but other explanations can be offered for the deterioration in the labour market position of the low paid in France. 


\subsection{Netheriands}

National minimum wage regulations have existed in the Netherlands since the Second World War, but the current system dates from an Act of 1968. Initially only workers aged 24 or over were covered, but this was changed to 23 or older in 1970 , and youth minimum wages (albeit at a lower rate) were introduced in 1974. The minimum wage for youths is expressed as a fraction of the full rate, with the fraction ranging from $30 \%$ for 15 -year-olds to $85 \%$ for 22 -year-olds, and there being a separate minimum wage for each year of age. Initially the minimum wage was indexed to average private sector wage growth, but this indexation was stopped in 1982. In 1984 the minimum wage was actually reduced by $3 \%$ in nominal terms and it has remained fixed in nominal terms since that date. The effect of this change can be seen in the Kaitz index in Figure 1. The Kaitz index rose from 1964 to 1981 , since when it has fallen back to slightly below where it was in 1964, although it remains at a fairly high level by international standards in the 1990s. Looking at wage distributions suggests that the proportion of workers paid the minimum has fallen over the 1980s, with substantial numbers left in relatively few sectors like retail and cleaning.

There are two other complications worth noting. First, something like $75 \%$ of workers are covered by sectoral wage bargains between employers and unions (what are known as CAOs), which also set minimum wages. These are typically higher than the legal minimum, with the gap being larger for younger workers. This means that the gap between the youth and adult minimum may not be as large as the legal minirnum might suggest. But most of the CAOs followed the legal minimum in reducing the youth minimum in 1981 and 1984 and nominal minimum wages in 1984 (although the adult rates were reduced less often than the youth rates). As a result, the time-series and cross-sectional variation in minimum wages is not really affected by the role of the CAOs.

Second, it should also be noted that unemployment benefits are directly linked to the minimum wage, so that all the changes in the minimum wage implied changes in benefit levels as well. This obviously makes it difficult (if not impossible) to disentangle the effects of benefit changes from minimum wages, even though these effects might be different. The Netherlands is a country in which there has been a relatively large amount of research into the employment effects of minimum wages. Perhaps more than in any other country this research has made use of 'structural' models of the labour market. So van Soest $(1989,1994)$ estimates a variant of the Meyer and Wise (1983a, 1983b) model and Koning et al. (1994) estimate a fully specified search model of the labour market. Both studies claim to find very large negative employment effects of minimum wages, but do so using data in which there is effectively no variation in minimum wages. In both cases the methods used to identify the effect of minimum wages on employment are rather dubious. In the case of van Soest (1994) 'identification of the minimum wage effect relies on model 
assumptions such as linearity and normality of error terms' (p. 106) in the author's own words. As there is no strong a priori reason to believe in these assumptions, and there are no specification or robustness tests, one should be a little uncomfortable with the results. And Koning et al.(1994) choose to estimate a variant of the search model in which the minimum wage is constrained to reduce employment (so the only issue is the size of the effect) and then seemingly estimate the size of the effect by looking at the rate at which exit rates from unemployment decline with unemployment duration, ignoring the large amount of research into other possible reasons for this phenomenon. ${ }^{8}$

Here we take a simpler approach to analysis of the employment effects of the minimum wage, but one that has the considerable virtue of using variation in minimum wages to look at employment effects. The biggest change in the operation of the system was a change in the youth minimum rates relative to adult rates in 1981 and 1983 . The fraction of the adult minimum received by 20 -year-olds went from $77.5 \%$ to $61.5 \%$, and by 16 -year-olds from $47.5 \%$ to $34.5 \%$ (Mot and Teulings, 1990). This had the expected effect on wages. While wages for those aged 23 or more increased by $9 \%$ from 1980 to 1984 , the wage for those aged less than 23 actually fell, with the largest falls for the youngest workers (the wage of 17-yearolds fell by $14 \%$ ). This is consistent with evidence that many young workers were receiving the minimum wage in 1979 and strongly suggests that minimum wages or benefits or both were important constraints on the wage distribution in this period.

Now consider the employment effects. In the whole economy, the share of youth employment fell from $19.4 \%$ in 1979 to $16.4 \%$ in 1985 , perhaps partly because of shifts in demand against younger workers (during a severe recession) or because of a fall in their share in the working-age population; outcomes alone cannot be used to infer the effect of the minimum wage in isolation.

To try to avoid this problem, one might think of using the idea of Card (1992a) that this change should have a bigger impact in some areas of the economy than others, as we did in the French study above. Unfortunately, regional wage differentials are very small in the Netherlands, so that we cannot use this exact methodology. Rather we consider the effect on different occupations. Table 7 presents information on the nine occupations which are the most intensive users of youth labour (the share of employment of 17-22-year-olds is only $6 \%$ in the excluded occupations). These occupations differ in the level of wages. Unfortunately we have no data on wages, but we do have information on the educational attainment of the workers in these occupations, a good proxy of low-wage sectors. The occupations with a relatively high proportion of less educated workers are kitchen and household staff, agricultural labour, unskilled industrial labour and leather and textile workers.

\section{1. \% :}

${ }^{8}$ In fact, if one altered their structural model so that minimum wages could only raise employment, then one could use their estimate of the employment loss as the employment gain associated with the minimum wage. 
Table 7. Youth employment in selected occupations in the Netherlands, 1979-5

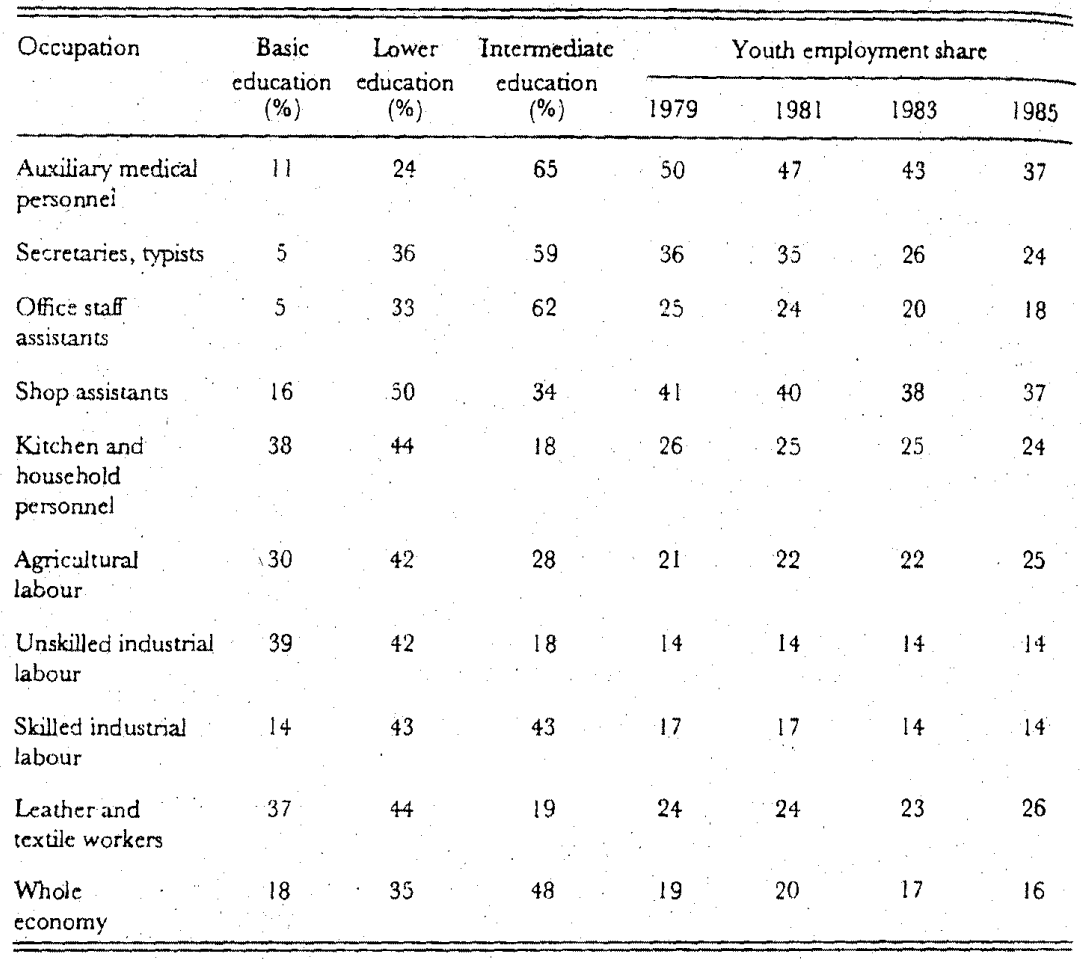

Notes: Youth employment refers to workers aged between 17 and 22 years. All employment figures are in full-time equivalents. Individuals with higher and university education are excluded, since they are usually unaffected by the minimum wage.

Source: Labour Warket Surce, 1979-85.

Did the 1981 and 1983 changes lead to changes in youth employment in these sectors relative to the rest of the economy? Since any observed changes might be caused by sectoral shocks, we consider changes in the share of youth employment (those aged 17-22) in total employment (measured in full-time equivalents) in lowwage occupations relative to the whole economy. The employment shares of young workers in these low-wage occupations over the period 1979-85 are presented in the final columns of Table 7. While the youth share of total employment in the whole economy fell over this period, that for kitchen and household staff went from $26 \%$ to $24 \%$, for agricultural labour from $21 \%$ to $25 \%$, for unskilled industrial labour from $14 \%$ to $14 \%$ and for leather and textile workers from $24 \%$ to $26 \%$. This is some indication that the cut in youth minimum wages did increase the relative employment of young workers relative to the economy as a whole in occupations most likely to be affected. However, these differences are, at best, on the margins of statistical significance. Also, if work within an occupation is relatively 
homogeneous, we would expect to see large substitution of adult for youth labour in the low-wage occupations: there is little evidence for this: So evidence from the Netherlands about the adverse employment effects of a minimum wage is scarcely compelling.

\subsection{Spain}

The current system of minimum wages in Spain, the salario minimo interprofesional (SMa), was introduced in 1963, replacing an earlier system in which minimum wages varied by region and age. It is a statutory minimum wage set by the government in consultation with trade unions and employer organizations, and its stated purpose (according to the Workers' Charter) is to protect wage earners and ensure 'a guarantee of their purchasing power and participation in the economic development of the nation'.

It currently sets one rate for workers aged 18 or over and one rate for those aged $16-17$ (although prior to 1990 it had set different rates for 16-year-olds) with special rates for homeworkers and casual/temporary workers. The change in youth rates in 1990 produced a very large rise in the minimum wages for teenagers, with an $83 \%$ increase for 16 -year-olds and a $15 \%$ increase for 17 -year-olds. We will study this episode in more detail below. At the start of 1994, apprenticeship contracts were introduced for workers under the age of 25 . These contracts must be between six months and three years in length and allow the employer to pay $70 \%$ of the SMI in the first year, $80 \%$ in the second and $90 \%$ in the third. Unemployment and health benefits are not included and they can be used by firms with fewer than 25 employees. But it is too soon for us to say what the effect of these schemes will be.

As in the Netherlands, the level of a number of welfare benefits is linked to the minimum wage. For example, unemployment assistance (paid after entitement to unemployment insurance has been exhausted) is generally $75 \%$ of the SMI (and $100 / 125 \%$ for unemployed heads of households aged 45 or more with $2 / 2+$ dependent relatives). Again this makes it very difficult to disentangle the effects of the level of benefits from the effects of the level of minimum wages per se.

As in the other countries, a major difficulty with assessing the impact of the minimum wage on the Spanish economy as a whole is that there is a national minimum that has varied very little in relation to average earnings (see Figure 1). It is obviously rather difficult to argue that the minimum wage is responsible for the high level of Spanish unemployment, since the Kaitz index is currently at a lower level than it has ever been in relation to average earnings. Any attempt to evaluate the overall effect is hampered by the lack of variation in the variable we wish to study, and any conclusions must be treated with caution. What we might hope to be able to do is to exploit not just the variation in the minimum wage over time, but also the fact that we would expect a given minimum wage to have more effect on low-wage industries. So we have investigated the relationship between minimum wages and employment 
using a panel of six sectors over the period 1967-94. In column (1) of Tables 8 a and $8 \mathrm{~b}$ we present a simple regression relating the change in employment to the change in the Kaitz index for the period 1967-94, controlling also for the rate of growth of sectoral output, the rate of growth of aggregate output and the rate of capacity utilization (to try to control for cyclical factors). The equations include sector-specific fixed effects and are estimated by instrumental variables (see the notes to Tables $8 \mathrm{a}$ and $8 \mathrm{~b})$. The Sargan instrument validity test does not reject the overidentifying restrictions in any instance. We do this exercise for both total employment and youth employment, the latter defined in terms of workers aged 16-19, since a finer definition of employment by age is not available for the whole sample.

As can be seen, there is a significantly positive relationship between the change in employment and the change in the Kaitz index for all workers, but a negative one for young workers (although only significant at the 10\% level). This suggests that minimum wages tend to reduce the employment of young workers, but to raise the employment of other workers by more. There are two concerns one might have about these results. First, they might be driven by the omission of relevant aggregate time-varying factors, a fear heightened by the fact that it is conventional to include dummy variables for each year in panel regressions of this type. But in this case, one can reject the hypothesis that these additional year effects are significant when they

Table Ba. The relationship between miaimura wages and total employment in Spain, 1967-94 (dependent variable: change in log employment)

\begin{tabular}{|c|c|c|c|c|c|c|c|c|}
\hline Data & $\begin{array}{l}\text { Panel } \\
\text { (I) }\end{array}$ & $\begin{array}{c}\text { Aggregate } \\
\text { (2) }\end{array}$ & $\begin{array}{l}\text { Energy } \\
\text { and } \\
\text { water } \\
\text { (3) }\end{array}$ & $\begin{array}{l}\text { Chemicals } \\
\text { (4) }\end{array}$ & $\begin{array}{c}\text { Engineering } \\
\text { (5) }\end{array}$ & $\begin{array}{c}\text { Other } \\
\text { manufacturing } \\
\text { (6) }\end{array}$ & $\begin{array}{c}\text { Construction } \\
\text { (7) }\end{array}$ & $\begin{array}{l}\text { Services } \\
\text { (8) }\end{array}$ \\
\hline $\begin{array}{l}\text { Change in } \\
\text { log Kaita } \\
\text { inder }\end{array}$ & $\begin{array}{c}0.082 \\
(0.019)\end{array}$ & $\begin{array}{c}0.077 \\
(0.045)\end{array}$ & $\begin{array}{c}0.044 \\
(0.024)\end{array}$ & $\begin{array}{c}0.063 \\
(0.021)\end{array}$ & $\begin{array}{r}0.056 \\
(0.031)\end{array}$ & $\begin{array}{c}0.134 \\
(0.033)\end{array}$ & $\begin{array}{l}0.136 \\
(0.042)\end{array}$ & \\
\hline $\begin{array}{l}\text { Change in } \\
\text { sectoral } \\
\text { output }\end{array}$ & $\begin{array}{c}0.296 \\
(0.062)\end{array}$ & $\begin{array}{l}0.329 \\
(0.148)\end{array}$ & $\begin{array}{c}0.332 \\
(0.154)\end{array}$ & $\begin{array}{c}0.273 \\
(0.136)\end{array}$ & $\begin{array}{c}0.416 \\
(0.168)\end{array}$ & $\begin{array}{c}0.832 \\
\langle 0.251)\end{array}$ & $\begin{array}{c}0.312 \\
(0.134)\end{array}$ & $\begin{array}{c}0.193 \\
(0,092)\end{array}$ \\
\hline $\begin{array}{l}\text { Lagged } \\
\text { change in } \\
\text { employment }\end{array}$ & $\begin{array}{c}0.338 \\
(0.156)\end{array}$ & $\begin{array}{c}0.329 \\
(0.148)\end{array}$ & $\begin{array}{c}0.273 \\
\langle 0.151\rangle\end{array}$ & $\begin{array}{c}0.169 \\
(0.082)\end{array}$ & $\begin{array}{c}0.263 \\
(0.104)\end{array}$ & $\begin{array}{l}0.331 \\
(0.096)\end{array}$ & $\begin{array}{c}0.352 \\
(0.111)\end{array}$ & $\begin{array}{c}0.293 \\
(0.164)\end{array}$ \\
\hline $\begin{array}{l}\text { Sargan } \\
\text { test }\end{array}$ & $\begin{array}{l}14.8 \\
(11)\end{array}$ & $\begin{array}{l}7.8 \\
(6)\end{array}$ & $\begin{array}{l}4.6 \\
(6)\end{array}$ & $\begin{array}{l}5.2 \\
(6)\end{array}$ & $\begin{array}{l}6.7 . \\
(6) .\end{array}$ & $\begin{array}{l}3.9 \\
(6)\end{array}$ & $\begin{array}{l}7.7 \\
\text { (6) }\end{array}$ & $\begin{array}{l}8.2 \\
(6)\end{array}$ \\
\hline $\begin{array}{l}\text { Serial } \\
\text { correlation }\end{array}$ & 0.8 & 1.3 & -1.2 & 1.1 & 0.8 & 0.6 & -0.3 & -0.5 \\
\hline
\end{tabular}

Notes: Equations also contain the following controls: foxed effects, change in log hours, change in log aggregate output and the aggregate capacity utilization me. The equation in column (1) also contains year effects when testing for their joint significance. The estimation method is IV. The instruments used are the controls listed above, sectoral fuxed effects, and lags of the real minimum wage, the real average wage, the change in output, the change in employment, the change in hours and the change in the sectoral price deflator. When testing for year effects, they are also included. In column (l) two lags are used. Heteroscedastic-consistent standard errors are reported in parentheses. Sargan test for the validity of the overidentifying restrictions. Degrees of freedom are in parentheses. The serial correlation is a $N(0.1)$ statistic for the presence of first-order serial correlation in the residuals.

Source: Contablidad Nocional Sectorial (various issues), and Garcia et al. (1994). 
Table $8 \mathrm{~b}$. The relationship between miximum wages and youth employment (16-19) in Spain, 1967-94 (dependent variable: change in log employment)

\begin{tabular}{|c|c|c|c|c|c|c|c|c|}
\hline Data & $\begin{array}{l}\text { Pancl } \\
\text { (1) }\end{array}$ & $\begin{array}{l}\text { Aggregate } \\
\text { (2) }\end{array}$ & $\begin{array}{l}\text { Energy } \\
\text { and } \\
\text { water } \\
\text { (3) }\end{array}$ & $\begin{array}{c}\text { Chernicals } \\
\text { (4) }\end{array}$ & $\begin{array}{l}\text { Engineering } \\
\text { (5) }\end{array}$ & $\begin{array}{c}\text { Other } \\
\text { manufacturing } \\
\text { (6) }\end{array}$ & $\begin{array}{l}\text { Construction } \\
\text { (7) }\end{array}$ & $\begin{array}{l}\text { Services } \\
\text { (8) }\end{array}$ \\
\hline $\begin{array}{l}\text { Ghange in } \\
\text { log Kaitz } \\
\text { index }\end{array}$ & $\begin{array}{l}-0.154 \\
(0.093)\end{array}$ & $\begin{array}{c}-0.096 \\
(0.073)\end{array}$ & $\begin{array}{c}0.036 \\
(0.031)\end{array}$ & $\begin{array}{r}-0.042 \\
(0.028)\end{array}$ & $\begin{array}{c}-0.096 \\
(0.083)\end{array}$ & $\begin{array}{c}-0.164 \\
(0.081)\end{array}$ & $\begin{array}{r}-0.216 \\
(0.112)\end{array}$ & $\begin{array}{c}-0.194 \\
(0.106)\end{array}$ \\
\hline $\begin{array}{l}\text { Change in } \\
\text { sectoral } \\
\text { output }\end{array}$ & $\begin{array}{c}0.448 \\
(0.122)\end{array}$ & $\begin{array}{r}0.612 \\
(0.246)\end{array}$ & $\begin{array}{c}0.492 \\
(0.163)\end{array}$ & $\begin{array}{c}0.536 \\
(0.212)\end{array}$ & $\begin{array}{c}0.443 \\
(0.203)\end{array}$ & $\begin{array}{l}0.962 \\
(0.272)\end{array}$ & $\begin{array}{c}0.446 \\
(0.176)\end{array}$ & $\begin{array}{l}0.282 \\
(0.100)\end{array}$ \\
\hline $\begin{array}{l}\text { Lagged } \\
\text { change in } \\
\text { employment }\end{array}$ & $\begin{array}{c}0.232 \\
(0.086)\end{array}$ & $\begin{array}{c}0.279 \\
(0.128)\end{array}$ & $\begin{array}{c}0.362 \\
(0.154)\end{array}$ & $\begin{array}{c}0.202 \\
(0.122)\end{array}$ & $\begin{array}{c}0.193 \\
(0.077)\end{array}$ & $\begin{array}{c}0.431 \\
(0.182)\end{array}$ & $\begin{array}{c}0.331 \\
(0.126) \\
1\end{array}$ & $\begin{array}{r}-0.036 \\
(0.056)\end{array}$ \\
\hline $\begin{array}{l}\text { No. of } \\
\text { observations }\end{array}$ & 168 & 28 & 28 & 28 & 28 & 28 & 28 & 28 \\
\hline $\begin{array}{l}\text { Sargan } \\
\text { test }\end{array}$ & $\begin{array}{l}11.4 \\
\text { (II) }\end{array}$ & $\begin{array}{l}9.8 \\
(6)\end{array}$ & $\begin{array}{l}8.3 \\
(6)\end{array}$ & $\begin{array}{l}6.4 \\
(6)\end{array}$ & $\begin{array}{l}5.9 \\
(6)\end{array}$ & $\begin{array}{l}6.3 \\
(6)\end{array}$ & $\begin{array}{l}8.7 \\
(6)\end{array}$ & $\begin{array}{l}9.3 \\
(6)\end{array}$ \\
\hline $\begin{array}{l}\text { Serial } \\
\text { correlation }\end{array}$ & -1.2 & 1.6 & -1.3 & -0.8 & 1.8 & 1.6 & 0.3 & -0.4 \\
\hline
\end{tabular}

Noles: As for Table $8 \mathrm{a}$.

are added both to the regressors and to the instruments, so that the specification presented is a parsimonious representation of the data. A second fear is that the results are driven by the cross-section variation in the Kaitz index, which is itself driven by cross-section variation in industry wages rather than the minimum wage. It would then be very dangerous to interpret the results as saying anything about the effect of the minimum wage. But the final six columns of Tables $8 \mathrm{a}$ and $8 \mathrm{~b}$ show that essentially the same correlations between changes in employment and changes in the Kaitz index apply within sectors as well as between them. The fact that estimated effects of the Kaitz index are largest in the sectors where the minimum wage is most important (sectors (4), (5) and (6)) gives some reason to believe that we are picking up effects of the minimum wage in this regression. So, while one must exercise some caution in interpreting the results, since there is relatively little variation in minimum wages in Spain, which increases the danger that the results are caused by some other factor, there does seem to be evidence that the minimum wage increases total employment while reducing that of youths.

However, there is one episode in recent Spanish history in which there has been a large change in minimum wages, and this episode deserves detailed study. This is the change in 1990 when the minimum wage for those aged 16 and under was raised to the level for workers aged 17. Figure 6 shows that this change caused a very dramatic rise in the youth Kaitz index. How was the employment rate of young workers affected relative to that of older workers? Since we expect the minimum wage to have the largest impact on employment in the low-wage regions, we plot the change in employment rates over the period 1990-4 (after the change) against the 


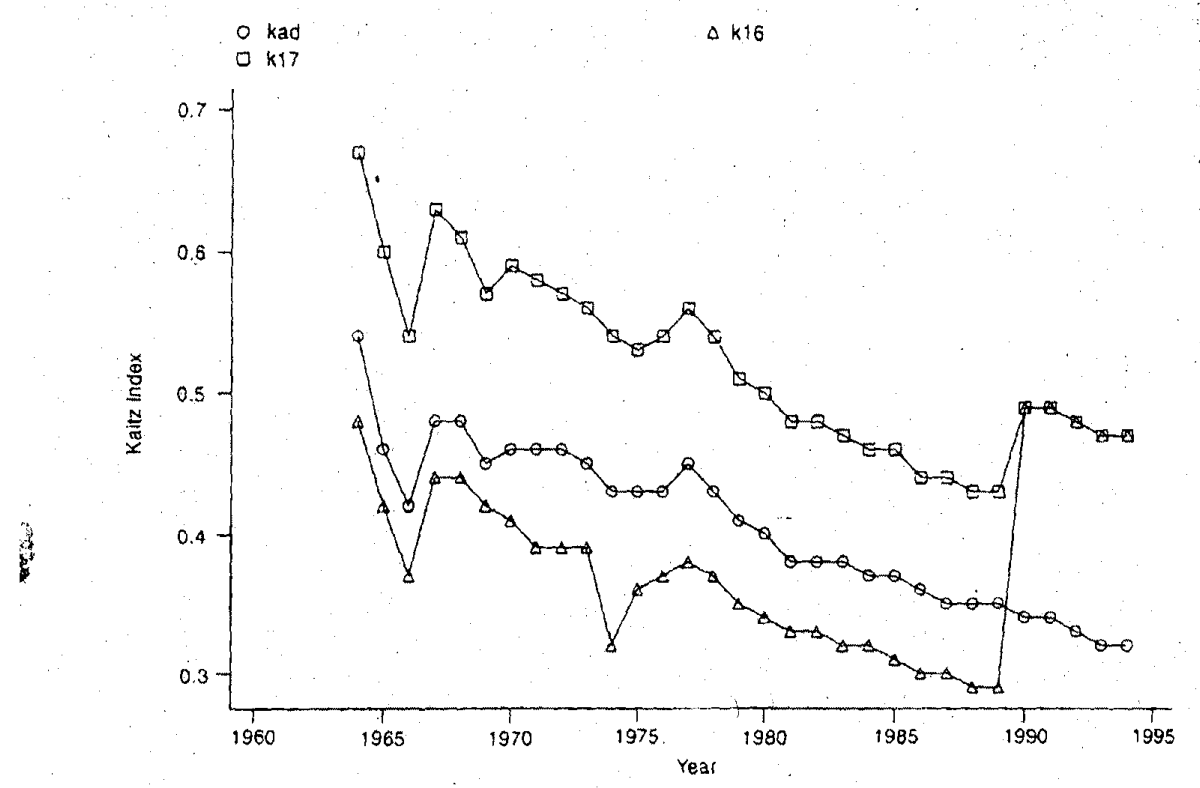

Figure 6: Kaitz indices for differeat age groups in Spain

Notes: kad is the adult Kaitz index; $\mathrm{k} 17$ is the Kaitz index for 17 -year-olds; and $\mathrm{k} 16$ is the Kaitz index for those aged less than 17 .

Sources: As in Figure 2.

fraction of workers in the region who were low paid in 1989 (before the change). Figure 7 a shows what has happened to the employment rates of the youngest workers (aged 16-19) and Figure $7 \mathrm{~b}$ shows what has happened to slightly older workers (those aged 20-4).

Figure 7 a suggests that this rise in the minimum wage reduced the employment of youths, while Figure $7 \mathrm{~b}$ suggests that the employment of slightly older workers increased. These results remain the same when one estimates regressions controlling for other factors, such as the overall employment rate for adult workers (to control for cyclical factors). The most plausible explanation for the employment effect on older workers is substitution of employers away from younger workers who had become relatively more expensive. If the substitution effect is the dominant one in this episode, one might also wonder if it can explain the time-series results reported earlier. There are two reasons why this is unlikely to be the case. First, it is very unlikely that total employment would rise if a rise in the minimum wage reduced teenage employment with a substitution effect for older workers: yet that is what the time-series results of Table 8 suggest. Second, we regressed the changes in the employment rate of the 20-64 age group on the adult Kaitz index, the changes in the employment rate of workers aged $16-19$ and controls for region and a trend. If substitution were all that mattered, we would expect to see no effect from the Kaitz 


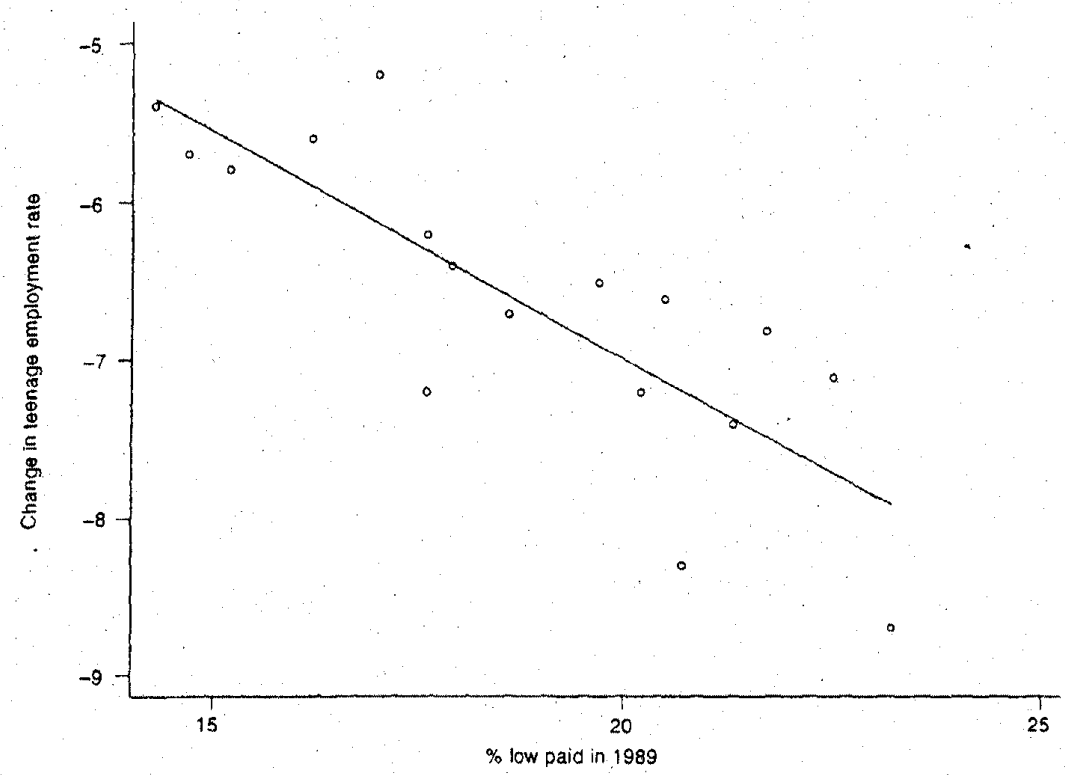

Figure 7.a. Changes in teenage employment rates in Spanish regions, 1990-4

Notes: The solid line is the regression line from a regression of the change in the teenage employment rate (those aged 16 - 19) from 1990 to 1994 on the proportion low paid in 1989.

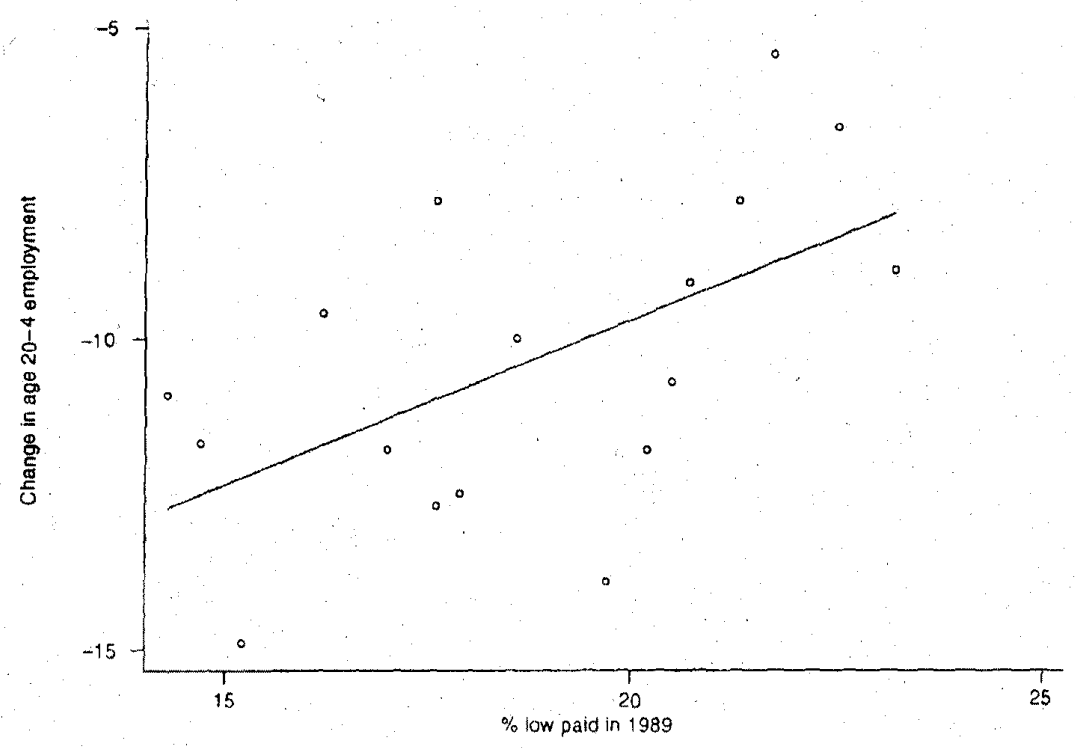

Figure $7 \mathrm{~b}$. Changes in employment rates of slightly older workers in Spanish regions, $1990-4$

Notes: The solid line is the regression line from a regression of the change in the employment rate of those aged 20-4 from 1990 to 1994 on the proportion low paid in 1989. 
index and a strong negative effect from the teenage employment rate. The coefficient on the teenage employment rate is -0.37 (standard error 0.12 ), suggesting that there is some substitution, but the coefficient on the Kaitz index is 0.09 (standard error 0.047), suggesting that the monopsony effect is still present. In conclusion, the evidence suggests that minimum wages reduced the employment of teenagers, but raised that of other workers; a conclusion in line with the time-series regressions reported earlier.

It is natural to want to try to reconcile these results with those of Card (1992a), who found no effect, or even a weakly positive effect, of the rise in the federal minimum wage in the USA in the early 1990s on teenage employment; and with those from France reported earlier. A first hypothesis might be that the level of the minimum wage is different in the two countries, the youth minimum being at a much higher level in Spain. If this is the case, it does not show up in the Kaitz index because the rise in the Spanish youth minimum led to a rise in the Kaitz index from slightly over 0.3 to slightly over 0.5 , whereas the change in the USA was from 0.75 to 0.85 . One could argue that it does show up in the spike, since approximately $25 \%$ of US teenagers receive the minimum wage, whereas the figure is closer to $40 \%$ in Spain. It is also possible that, whereas the minimum wage is virtually the only wage floor for teenage workers in the USA, the minimum wage has an important influence on higher wage floors ir Spain, so that the Kaitz index understates the importance of the minimum. Some evidence supportive of this view comes from the survey 'Collective Bargaining in Large Firms' for 1985 and 1994. The ratio of the wage of labourers (the lowest skill category) to the wage of workers aged 16 and 17 fell from 1.83 in 1985 to 1.31 in 1994 (and was even lower in some sectors). As these negotiated wages are generally above the minimum, this suggests that the rise in the relative wages of youths was not confined to workers paid the minimum wage. The rise in the youth minimum wage may have had a considerable impact on the wages of young workers paid above the minimum.

To conclude, we do have evidence from Spain that rising minimum wages in the early 1990s have reduced youth employment. But the evidence also suggests a rise in total employment. One should not conclude that the minimum wage must necessarily be bad for the labour market.

\subsection{United Kingdom}

The Wages Councils were established by Winston Churchill in 1909 to protect the pay of workers in the 'sweated' trades. They set minimum wage rates in a number of different industries. Over the years, the number of industries covered first increased (to a peak of about 60 covered sectors in the early 1960s), then decreased, and by the early 1990s the 26 remaining Wages Councils set minimum wages for approximately 2.5 million workers in low-paid sectors (mostly in hotels and catering, retail, clothing manufacture and hairdressing, but also in a number of very small 
industries). If we define the low paid as those earning less than $£ 3.50$ per hour, then $35-40 \%$ of these workers were in Wages Council sectors. Each Wages Council consisted of an equal number of employer and worker representatives, plus a maximum of three independent members (nominated by the government of the day) who had the casting vote if an agreement was not reached. Until the 1986 Wages Act, the Councils generally set a myriad of minimum wages differentiated by age, occupation and region, but after 1986 they set only a single rate for those aged 21 or over and the minimum wage for younger workers was abolished. The 1993 Tracie Union Reform and Employment Rights Act abclished the remaining 26 Councils. Since 1993 there have been no minimum wages in operation except in agriculture, where, for the moment, the Agricultural Wages Boards still exist.

As the rates set by the Wages Councils varied both across industries and over time, it is natural to use a panel of industries to investigate the effect of minimum wages on employment. We have done this elsewhere (Machin and Manning, 1994; Dickens et al., 1994a). The results can be most succinctly summarized with a diagram. Figure 8 plots the change in employment against the change in the Kaitz index for the period 1975-92. Each dot represents an observation for a particular Wages Council in a particular year. There is a positive relationship between these two variables, suggesting that industries and years in which minimum wages rose fast relative to average wages were associated with faster than average growth in employment. A simple picture cannot control for a host of factors that might explain these results, but our regression analysis suggests that the finding is surprisingly robust. ${ }^{9}$ We found similar results when we looked at agriculture alone (Dickens et al., 1995).

The recent experience of the UK also offers an opportunity to study the effect of a dramatic change in the minimum wage system: namely, the abolition of the Wages Councils (except in agriculture) in August 1993. One might expect sudden, and possibly large, falls in wages and to be able to investigate the effect on employment. Such dramatic falls in wages never happened. Figure 9 a shows the distribution of wages in retail (the largest Wages Council) in April 1993, immediately prior to abolition. The minimum wage is at the spike in the wage distribution: its influence can be clearly seen. Figure $9 \mathrm{~b}$ shows what the distribution of wages looked like in retail in April 1994, six months after abolition. The most striking feature is that the spike at the old minimum, although reduced, is still noticeable.

There are a number of reasons why the minimum continues to exert an influence on the wage distribution even after abolition. First, any worker employed prior to 30 August 1993 has a right to the same terms and conditions of employment after that date if he or she remains with the same employer. Any attempt to cut wages by the

\section{\%:}

${ }^{9}$ We attempted to control for potential endogeneity of the mininum wage, differences in employment growth rates by industry, and differences in short- and long-run effects, and we used alternative measures of employment. Our results were always the same. 


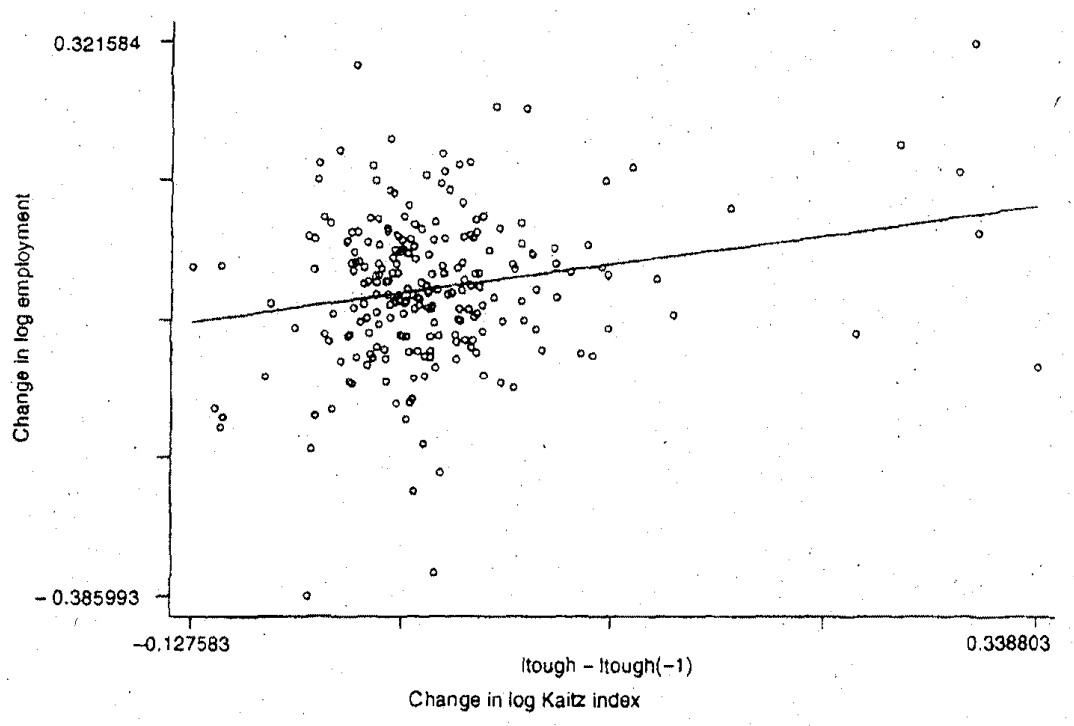

Figure 8. Changes in employment and the Kaitz index in UX Wages Coumcil industries, 1975-92

Notes: Each observation represents a change in log employment and a change in the log Kaitz index in a particular year in a particular Wages Council where we distinguish between men and women. The solid line is the fitted regression line.

employer could be argued by the worker to be constructive dismissal, for which redress could be sought under the 1986 Wages Act. ${ }^{10}$ Effectively, the minimum wage is still in force for existing workers and it is only the wages of new employees that the employer can lower. Even this freedom is curtailed by limits on the extent to which employers are prepared to pay different wages to workers doing the sarne job, and by considerable resistance to nominal wage cuts. Reasons for these practices are not fully understood, but they are a powerful influence on wage formation.

The minimum wage rates set by the Wages Councils prior to abolition will probably continue to exert an influence on the bottom of the wage distribution for some time to come, but their importance is reduced as inflation and real-wage growth cause them to fall in relation to average earnings. Some employers also cut wages for new workers. Table 9 shows that wage growth in the old Wages Council industries was slower in the period 1993-4, although the difference is modest. And a survey of vacancies by the Low Pay Network found that a significant proportion of vacancies were at pay rates below the old minimum rates (although again a significant proportion are still at the old minirnum rates).

\section{\%.:}

${ }^{10}$ Many low.paid workers are unaware of their rights or are in no position to enforce them; some existing workers may also experience wage cuts. 
(a) April 1993 (atter abolition)

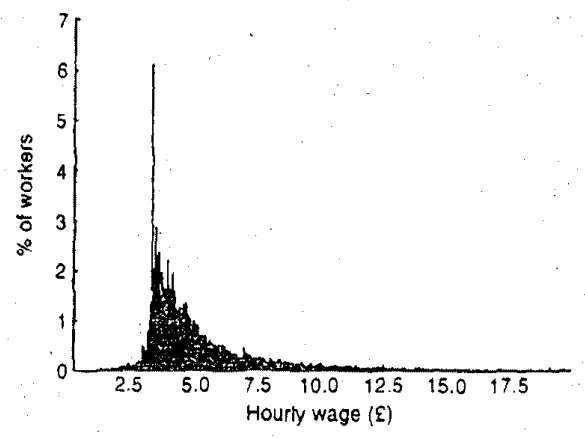

(b) April 1994 (after abolition)

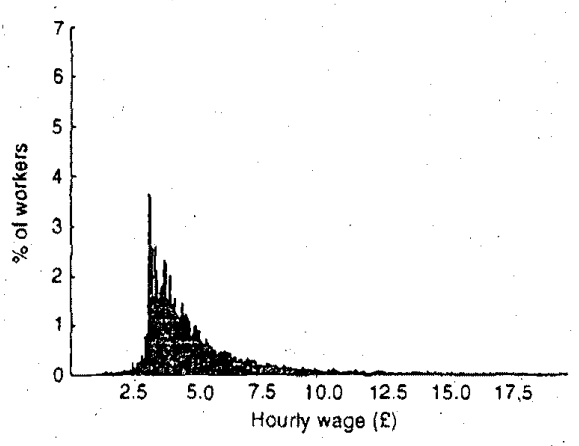

Figure 9. The distribution of wages in the UK retail sector Source: New Eamings Survey.

With only modest immediate effects on wages, we are unlikely to discover significant effects on employment. Table 10 presents information on the share of employment in the Wages Council industries; there is no evidence of dramatic changes in employment. But just as we might expect to see the first effect of abolition on wages in the wages being offered to new workers, so we might expect to see the first effect in employment on hiring and exit rates from the Wages Council sectors. Table 11 presents information for the quarters immediately before and after abolition. There is no noticeable change in the behaviour of the Wages Council sector relative to the rest of the economy.

There is good reason to believe that the abolition of the Wages Councils will reduce wages in the long run, but effects will take a long time to work through, making it hard to identify any effects on employment. But this evidence from the period of operation of the Wages Councils provides no evidence that their activities were associated with job losses. 
Table 9. Average wages in Wages Council industries, April 1991-April 1994

\begin{tabular}{|c|c|c|c|c|c|c|c|}
\hline \multirow[t]{2}{*}{ Industry } & \multicolumn{4}{|c|}{ Average hourly earnings $(E)$, in April } & \multicolumn{3}{|c|}{ Arnual $\%$ change during: } \\
\hline & 1991 & 1992 & 1993 & 1994 & $91 / 92$ & $92 / 93$ & $93 / 94$ \\
\hline Clothing & 4.11 & 4.39 & 4.59 & 4.83 & 6.6 & 4.7 & 5.2 \\
\hline Catering & 4.04 & 4.20 & 4.30 & 4.42 & 3.9 & 2.3 & 2.7 \\
\hline Hairdressing & 3.33 & 3.59 & 3.86 & 3.91 & 7.6 & 7.6 & 1.4 \\
\hline Retail & 4.75 & 5.04 & 5.30 & 5.35 & 6.2 & 5.0 & 1.0 \\
\hline All Wages & 4.59 & 4.87 & 5.07 & 5.16 & 6.9 & 4.1 & 1.7 \\
\hline Councils (WC) & & & & & & & \\
\hline $\begin{array}{l}\text { Ail non-WC } \\
\text { industries } \\
\text { (SIC 0-9). }\end{array}$ & 6.85 & 7.35 & 7.66 & 7.89 & 7.3 & 4.3 & 2.9 \\
\hline $\begin{array}{l}\text { All non-WC } \\
\text { service inds } \\
\text { (SIC 6-9) }\end{array}$ & 6.93 & 7.45 & 7.76 & 8.0 & 7.4 & 4.2 & 2.9 \\
\hline
\end{tabular}

Notes: 'All Wages Councils' includes Clothing Manufacture, Retail Food, Retail Non-Food, Unlicensed Place of Refreshment, Licensed Residential and Restaurant, Licensed Non-Residential, Hairdressing, Boot and Shoe Repair, Laundry, Hat Cap and Millinery, Linen and Cotton Handkerchief, Made Up Textiles, Rope, Twine and Net, Fur Goods, Toy Manufacture and Soft Drinks Manufacture. Soutce: New Eamings Survey Micro Data.

Table 10. Employees in employment in Wages Council industries (thousamds), Great Britain

\begin{tabular}{lccc|cc}
\hline & $\begin{array}{c}\text { June-Aug } \\
1992\end{array}$ & $\begin{array}{c}\text { Dec. 1992- } \\
\text { Feb. 1993 }\end{array}$ & $\begin{array}{c}\text { June-Aug. } \\
1993\end{array}$ & $\begin{array}{c}\text { Dec. 1993- } \\
\text { Feb. 1994 }\end{array}$ & $\begin{array}{c}\text { Sept.-Nov. } \\
1994\end{array}$ \\
\hline $\begin{array}{l}\text { All WC industries } \\
\text { All other inds }\end{array}$ & 2420 & 2374 & 2436 & 2421 & 2461 \\
$\begin{array}{l}\text { WC employment } \\
\text { as \% of total }\end{array}$ & 18466 & 18183 & 18370 & 18185 & 18481 \\
\hline
\end{tabular}

Notes: Abolition of the Wages Councils took place at the end of August 1993.

Source: Quarterly Labour Force Survey Micro Data.

Table 11. Hiring and exit rates in Wages Council and other industries

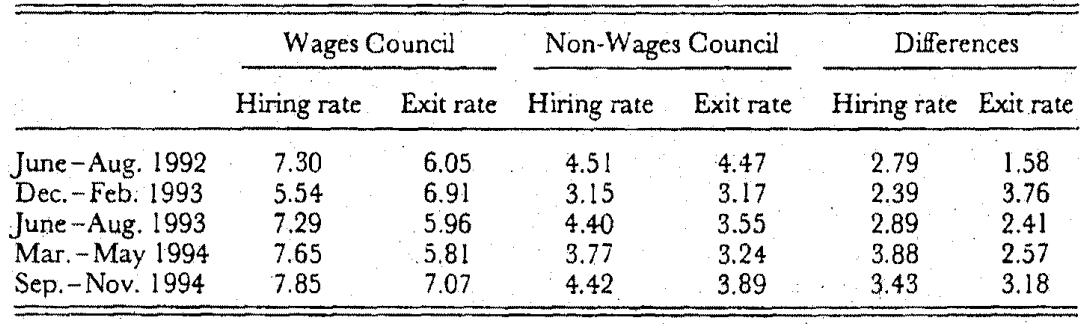

Notes: The hiring rate is the fraction of workers in the sector (WC or non-WC) who were not in it in the previous quarter. The exit rate is the fraction of workers in a sector who had left it by the following quarter. The Wages Councils were abolished in August 1993.

Source: As in Table 10. 


\section{CONCLUSIONS}

Much policy discussion about European labour markets suggests that abolition of the minimum wage is a key issue. We hope to have painted a more balanced view. The importance of minimum wages has probajly been exaggerated.

The theoretical effect of minimum wages on employment depends on details of the labour market in which it is imposed. The effect can in theory go either way. Detailed evidence is needed before judgements can be drawn. The common perception that the theoretical case is clear cut is simply incorrect. From our empirical analysis we draw four main conclusions.

In most European countries, there has been little change in minimum wages relative to average earnings over the past 30 years. It is hard to argue that the minimum wage has played a large part in the rise in European unemployment over this period.

While minimum wages do seem higher in relation to average eamings in Europe than in the USA for adults, the opposite is often true for young workers: there is extensive variation in the minimum wage by age in Europe and very limited variation in the USA.

Although much policy discussion surrounding the minimum wage focuses on the effects on the youth labour market, these workers make up a rather small and declining proportion of minimum wage workers. Increasingly, minimum wage workers are women, temporary and part-time workers.

The evidence on the employment effects of minimum wages is very mixed. We have found evidence that higher minimum wages reduced employment in some cases (particularly for young workers) and raised it in others (particularly for total employment). But it is surprisingly hard to find strong evidence of any adverse employment effects of minimum wages in situations where many commentators are firmly convinced (rightly or wrongly) that the job losses exist: France in the 1980s is a good example of this. As the employment effects of minimum wages on the youth labour market do seem to be worse, there is a strong case for having a lower minimum wage for young workers.

We should emphasize that none of our results suggests that the effects (good or bad) on the economy of current levels of minimum wages are particularly large. The presence or absence of a minimum wage will not be the difference between economic success and failure.

\section{Discussion}

\section{Gilles Saint-Paul \\ CERAS, DELTA and CEPR}

As we all know, economics is strongly dependent upon fads and fashions. A currently fashionable view, which started across the Atlantic, and is exemplified by 
the work of David Card and Allan Krueger, is that the minimum wage increases employment. The idea is that, if monopsony power is prevalent, firms are artificially reducing the wage below the marginal product of labour, so that a minimum wage, rather than reducing labour demand; would simply cut into their monopsony markup; at the same time labour supply increases, so that the net employment effect is positive. This idea is backed by some evidence: for example, on the fast-food industry in New Jersey and Pennsylvania.

Given that minimum wages are typically much more binding in Europe than in the USA (see the authors' Table 1), and are a key suspect for high unemployment in Europe, it is essential for policy purposes to examine whether the conclusions of Card and Krueger are valid in Europe. At the same time, the variety of minimum wage legislations in Europe offers a useful laboratory in order to assess the impact of various levels of minimum wages on employment. The paper by Dolado et al. is therefore a very welcome contribution to the literature.

How seriously should we take this argument that the minimum wage is good, at least over some range, for employment? Several remarks are in order. First, it is an argument about employment, not unemployment. It tells us that the minimum wage will increase labour supply and that, when it is introduced, firms will be willing, at the margin, to absorb this excess labour supply because of a wedge between the marginal product of labour and the wage. To know whether unemployment will rise or fall, we need a model of unemployment. Monopsony per se does not generate involuntary unemployment; everybody is able to find a job at the current wage. In the pure monopsony model, employment rises but the economy is and stays at full employment until the minimum wage equals the Walrasian equalibrium one. To get unemployment we must introduce a distinction between the wage formation schedule and the Walrasian labour supply curve. My intuition tells me that the net effect on unemployment depends on the relative steepness of these two schedules. All this is important, since part of the evidence which is presented has to do with unemployment rather than employment.

Sccond, analysis is mostly a partial equilibrium, at firm level. We know that a firm facing an upward-sloping supply curve will increase employment; we do not know what happens in the economy as a whole. In particular, the aggregate labour supply curve may be much steeper than the one faced by an individual firm, since the latter reflects the possibility for workers to move across regions and/or sectors. So in the aggregate, increases in the minimum wage would show up in higher wages with little or no effect on employment.

Third, the scope for increasing employment by means of an increase in the minimum wage depends on the extent of the individual firms' monopsonty power. The fact that we notice a spike at the minimum wage in the distribution of income is itself evidence in favour of monopsony; if productivity were smoothly distributed across workers and if these were paid their marginal product, minimum wages would truncate the distribution of income but not create a mass of people at the 
minimum wage. On the other hand, there are many sectors in which I find it hard to believe in monopsony. This particularly applies to the original Card and Krueger finding about the fast-food industry in New Jersey. As far as I know, this is a very densely populated state; furthermore, the US fast-food industry is extremely competitive; there are many competing furms having the same location (shopping malls, food halls), offering highly substitutable products (pizza, hamburgers, Chinese food, etc.) and all employing the same sort of low-skilled labour. This sounds to me like one of the worst candidates for monopsony (and monopoly) one might think of. So it is important to think of other explanations. One possibility is the Rebitzer and Taylor (1995) paper, which is based on efficiency wage considerations and has predictions quite similar to monopsony models. Another argument can be made more in line with the European context. Assume that there are two types of worker, permanent and temporary. Assume that permanent workers have a high firing cost and are paid above the minimum wage, while temporary ones are paid the minimum wage and have no firing cost. Under some circumstances, the firm will hire both permanent and temporary workers. A rise in the minimum wage will induce it to substitute permanent for temporary workers. Now, because permanent workers have a high firing cost, in a slump the firm will fire only temporary workers. Because it has more permanent workers following the rise in the minimum wage, total employment may well increase due to the contribution of those firms which are in a slump. Thus, the minimum wage acts as a 'shadow firing cost'; increasing it is like increasing firing costs, which we know may be favourable for aggregate employment by preventing firms from firing.

Fourth, there is a great deal of market imperfection elsewhere in the economy, in particular on the labour supply side; this calls for maximum, rather than minimum wages. We do not see many proposals going in that direction. For any existing institution, it is possible to think of a distortion that makes this institution have beneficial effects. But this is different from saying that this institution is the most adequate, or even was intended, to cure the inefficiency.

If minimum wages increased employment, politicians would have surely found out, as raising minimum wages would certainly be a popular and uncontroversial measure. Yet in France, when the minimum wage is increased, the government often offsets its impact on unskilled labour costs by reducing social security contributions. Evidence on US congressional voting suggests that states with a higher proportion of youth in their workforce are actually more likely to oppose increases in the minimum wage (Uri and Mixon, 1980); that would be strange if higher minimum wages were to raise both the income and employment level of the young. Now, it may just be the case that the voice of orthodox economists is soloud that they are perversely preventing a political free lunch from being eaten ...

Turning now to the empirical evidence, a key, but unavoidable, problem with the authors' approach is that it is impossible to design a control group for which the minimum wage evolved differently, since wo are dealing here with national 
minimum wages applying to everybody. Therefore, the explanatory variable has to be some proxy like the proportion of workers paid the minimum wage or the Kaitz index, and all the cross-sectional variation in such proxy will be driven by factors other than the minimum wage. This raises many simultaneity problems. For example, in Table 5, the coefficient of the change in employment (or unemployment) rate on the proportion paid near the SMIC may be biased, since any source of unemployment other than the minimum wage will push wages down, thus increasing the proportion of workers paid near the SMIC. Similarly, in Table 6, which leads to opposite conclusions; a positive employment impact of minimum wages is inferred from the evidence of higher employment growth in regions with initially lower wages. The argument is, again, that minimum wages are more biting in such regions. But, again, it is hard to believe that the cross-sectional variance in employment growth is entirely driven by changes in the national minimum wages. Any model with partial adjustment of employment and region-specific wage shocks will predict a negative correlation between initial wages and subsequent employment growth. A similar argument may apply to Figure 9: a positive regression coefficient of employment on the Kaitz index may simply point to a negative correlation berween employment and average wages, i.e. we are simply recovering a labour demand curve. This will prevail if cross-section variations in wages are driven by differences in wage pressure (e.g. different unionization rates).

\section{Michael Keen}

\section{University of Essex}

The economic impact of minimum wage legislation is a fearsomely contentious topic, both academically and politically. This paper does great service both to outsiders like me and, I have no doubt, to those working in the area, in providing a level-headed, painstaking and thoughtful European perspective on some of the principal issues at stake. In these brief comments I seek only to raise some of the wider policy questions that the paper prompts but does not dwell on.

The central focus of the paper is on the employment effects of the minimum wage. This is right and proper, given the policy priority that ought to be attached to unemployment in Europe and, of course, recent empirical and theoretical developments suggesting that these effects are not as straightforwardly bad as had been widely believed. Nevertheless, employment itself is typically not an appropriate maximand for policy design. The minimum wage, as the paper makes clear, is best thought of as just one potential weapon in a wider attack on poverty (and/or inequality). Understanding the employment effects of the minimum wage is an important first step in understanding its potential value as a component of poverty alleviation strategies; but it is only a first step. Moreover, policy must be made before that first step can be taken with full confidence. Tony Blair, leader of the British Labour Party and apparently prime minister in waiting, will at some point (probably) have to specify an exact figure for the minimum wage to which he is 
committed, and might reasonably look to the profession for some guidance as to the level at which it should be set and, more broadly, on the role of the minimum wage in a well-designed poverty alleviation programme. It is not clear that we can yet provide as much guidance on these matters as he might have hoped. Indeed, Card and Krueger (1995, p. 393) themselves call for 'a reorientation of policy discussions away from the efficiency aspects of the minimum wage and towards distributional issues'. Several authors have indeed provided elements of such a reorientation, notably Freeman (1996), Guesnerie and Roberts (1987), Marceau and Boadway (1994) and Saint-Paul (1994). But it remains the case that the minimum wage has been only imperfectly integrated into the analysis of poverty aileviation.

To see some of the issues that may arise in moving towards such an integration, many of which have indeed been noted by the authors just mentioned, it may help to start with a very simple example. Suppose that the object of policy is to maximize a social welfare function of the familiar form

$$
\frac{1}{1-\sigma}\left(\sum_{h}\left(y_{h}\right)^{1-\sigma}\right)
$$

where $y_{h}$ is the income of individual $h$ and higher values of the parameter $\sigma \geqslant 0$ correspond to increases in inequality aversion: $\sigma=0$ is utilitarian, $\sigma+\infty$ is the Rawlsian maximin case. "Suppose too that there are only two kinds of person: those who find work at the minimum wage $w$ and those who instead take unemployment benefit at the rate $b$ (which we treat as fixed). Take the proportion of the population in the former group to be $e(w)$, this being thought of as the reduced form of some unspecified labour market model. In the competitive case, $e(w)$ is decreasing; in others - textbook monopsony, efficiency wages, matching - it may be increasing at first, but will surely be decreasing eventually. Choosing the minimum wage to maximize social welfare gives the necessary condition

$(1-\sigma) w^{1-\sigma}+E\left(b^{1-\sigma}-w^{1-\sigma}\right)=0$

where $E \equiv-e^{\prime} w / e$ is the elasticity of employment with respect to the minimum wage.

This provides an immediate reminder of an obvious but important point: at the optimum, $E>0$. That is, even if monopsony elements of the kind emphasized by Dolado et al. lead employment to increase with the minimum wage over some range, that minimum should be pushed to the point at which further increases reduce employment. This in turn has one implication that may have some empirical relevance: if the minimum wage is set optimally, disturbances to it must give an observed negative relationship between employment and the minimum wage. In richer models, of course, this may cease to be true. Nevertheless, the example

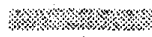

"The logarithmic case $\alpha-1$ is excluded for brevity 
suggests that there may be a sense in which the cards are stacked against observing a positive effect of the minimum wage on employment even if there is such an effect over some range.

Solving (1) gives

$\frac{w}{b}=\left[\frac{E}{E+\sigma-1}\right]^{1 / 1-\sigma}$

As one would expect, the optimal minimum wage increases with the level of unemployment benefit and decreases with the elasticity of labour demand. Intuitively, the impact of inequality aversion is less obvious. In so far as the minimum wage is usually rationalized in terms of distributional concerns - is thought of, broadly, as a 'leftist' tool - one might have expected the optimal minimum wage to increase with $\sigma$. But in so far as it diminishes employment, of course, the minimum wage has an adverse impact on the berween-group inequality of working and rion-working poor. Indeed, and somewhat surprisingly, this turns out to be the dominant effect in the present simple setting: it can be shown from (2) that (for given $E$ ) an increase in inequality aversion $\sigma$ unambiguously reduces the optimal minimum wage. Once seen, the reason is obvious: as inequality aversion increases, so the plight of the very poorest - those on benefit - becomes the overriding concern, and the object of policy becomes simply to maximize the number of employed. Thus the minimum wage may not, after all, be as 'left' a measure as commonly thought.

The framework just used is, of course, flagrantly stylized. Perhaps most obviously, it ignores both those employed at above the minimum wage and the revenue cost of financing unemployment benefits. The implications of the latter may also be more complex than at first seems, for the costliness of raising public funds to finance benefits for poverty relief might in itself seem to be an argument for a minimum wage. To the extent that the minimum wage is a tax on the distributionally relatively undeserving, the marginal social cost of financing transfers to workers by this route may be less than that of explicit transfers financed by taxes that may be both more distorting and less well targeted distributionally: may be less, that is, than the marginal cost of public funds (MCPF). But the framework here emphasizes that this natural line of thought may be incorrect, for in this setting one would expect a higher MCPF to lead to a lower minimum wage rather than a higher, because a higher MCPF means a higher cost to society of financing any given level of expenditure on unemployment benefit. In a richer model, this effect would need to be weighed against any saving that a minimum wage might bring in the cost of financing in-work benefits. The trade-of between the minimum wage and in-work benefits, with potentially divergent effects on both work incentives and tax revenues, may be a critical concern in designing the fully optimal minimum wage.

As the authors rightly emphasize, establishing the case for a minimum wage requires one to be persuaded that there is no better way of achieving the purpose in 
hand. In this context they highlight the potential importance of labour market structure, and indeed this will clearly have a crucial role in integrating the minimum wage into broader poverty alleviation strategies. Another set of considerations likely to be important may also deserve some emphasis: the nature of, and any constraints on, the tax instruments available to government. It is natural, after all, to conceive of the problem of putting together a poverty alleviation strategy in terms of the somewhat il-defined principle of targeting: the most effective policy is likely to be that which uses instruments most directly related to the quantities of concern. Take, fcr example, the argument that a minimum wage may help to overcome underinvestment in skill acquisition. Intuition suggests that a better policy response would be to act on that underinvestment directly, perhaps by an explicit subsidy. The advantage of such a targeted policy is that it may avoid unintended distortions: there may, for instance, be some who could never get their skills up to the level needed for them to warrant the minimum wage, and whom such a minimum would consequently condemn to unemployment. Thus one needs to know why a more precisely targeted intervention is not possible. Restrictions on tax instruments available to the government - a high MCPF inhibiting subsidies, for example, or problems associated with monitoring the uses to which educational loans are put - are likely to have an important role to play in justifying adoption of a minimum wage. They may even be indispensable.

Several examples of this general point come to mind. One is provided by Guesnerie and Roberts (1987). Imagine a world of competitive labour markets, and suppose first that the only redistributive instrument available is a linear income tax. There may then be a case for a binding minimum wage, essentially as a means by which the low paid can exploit their collective monopoly power If, however; the government is able to deploy fully non-linear taxation, the case for a minimum wage vanishes: the government is able to bring about the same exploitation of monopoly power by acting on labour supply decisions through the tax system, with no need to ration labour supply.

As a further instance of the same general principle, it may be that the minimum wage has advantages over other forms of income support in terms of take-up. In the $\mathrm{UK}$, for example, take-up of the main benefit to the working poor is very low (at around $60 \%$ of those entitled), a fact often attributed to stigma and/or hassle connected with claiming the benefit. No such disinclination to take-up is likely to be associated with the minimum wage. Thus it may be that the disadvantages associated with leakage of benefit of minimum wage to the low paid who do not belong to the poor households, a concern emphasized by the authors, may be offset by its greater reach. On the other hand, the same high take-up is just as likely to apply to other instruments that are administered through firms rather than people, such as a marginal employment subsidy. It may then be that the complexities of administering such schemes, and the possibilities for abuse, again leave something to be said for the minimum wage. 
One particular set of constraints on the instruments likely to be available are those implied by the continuing process of economic integration within Europe. While the paper touches on the possible implications of this for the impact of minimum wage rules, the obvious policy question lies outside its remit: does closer integration imply a case for co-ordinating minimum wage policies to avoid these minima being driven to excessively low levels?

The paper emphasizes the effects of integration in product markets. There may, however, be effects through other markets. The most obvious such effects are those through labour mobility. Views on the actual and prospective importance of labour movements in Europe vary rather widely, so I leave this aside. Effects through capital markets also deserve consideration. Moving from a situation in which capital is inmobile internationally to one in which it is perfectly mobile fattens the labour demand curve. The intuition here is simply that mobility enables capital to escape any burden of the minimum wage, so that an increase in the wage rate has a more dramatically negative impact on employment. One might then expect capital mobility to lower the minimum wage that is optimal from the perspective of any one country; and hence, perhaps, to strengthen the case for co-ordination of policy across countries. But there may be further effects through product markets pointing in the opposite direction. With monopsony elements, for example, a minimum wage may become a device for committing to high output; and thus, for the kind of reason familiar from the strategic trade literature, non-cooperative behaviour might lead to excessively high minimum wages. The prospect of closer integration may also affect the political equilibrium from which the minimum wage emerges: as capital becomes more mobile, so capital owners become more able to escape the burden of a minimum wage by instead investing abroad; they might then be inclined to oppose such minima less fiercely. Again, closer integration might for this reason conceivably lead to an increase in minimum wages rather than a reduction.

The minimum wage, it seems clear, will remain a contentious topic. We shall need more such well-balanced analyses as this,

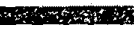

\section{General discussion}

The regressions and, in particular, the use of the Kaitz index in the regressions generated considerable discussion. Gene Grossman argued that regressing total employment on the Kaitz index was not very meaningful, and that the estimated coefficient was hard to interpret. He reasoned that the index - the ratio of the minimum to the average wage - could conceivably explain the ratio of skilled to unskilled workers in the workforce, but not the total level of employment. Its use in cross-section analysis was even more problematic, since it implicitly assumed that production functions are the same across industries. Mathias Dewatripont observed that trade unions of ten bargain over both the minimum wage and the average wage. In such a circumstance, which was usual in Belgium, it would be appropriate to 
include both as separate variables in the regression, rather than using merely their ratio. For David Begg the issue boiled down to whether changes in employment reflected a shift in the labour demand curve or movements along it. Alan Manning defended the use of the index. He argued that the alternative, to use the absolute level of minimum wages instead of the Kaitz index, would not be sensible because minimum wages vary over time with changes in productivity. Not correcting for this variation would bias the results in a serious way. The Kaitz index corrects for variations in productivity by deflating the minimum wage by the average wage; here the deflator is to be viewed only as a measure of average productivity.

The issue of how minimum wages are set in Europe drew various comments. Frederick van der Ploeg suggested that Greece and Spain, where wages are much below the European average, be included to give more balance to the enquiry. He also pointed out that there are two minimum wages to consider, since the legal minimum wage is quite different from the agreed minimum wage that obtains under collective bargaining. In the Netherlands, the gap between the two was as high as $10 \%$. Axel Weber added that, similarly, in Germany there was a distinction between contract wages and minimum wages. Further, given that the proportion of workers with minimum wage protection depends on the degree of unionization in a country, it would be useful to include unionization as a variable in the regressions. Gene Grossman argued that, to the extent that minimum wages in the UK were set sectorally by Wages Councils, there must be some political economy explanation for the differences in minimum wages across industries. This could make the evolution of minimum wages endogenous to industry evolution. Tryphon Kollintzas added that in Greece the effect of minimum wages on employment levels was hard to decipher, primarily because there were other rigidities in the labour market, most notably the high firing cost. Christian Dustmann took issue with the claim that the recent abolition of minimum wages in 1993-4 had not affected wages in the UK. $\mathrm{He}$ argued that the period under study was much too short to support such a strong claim, and that examining the new entrants' wages might reveal a more pronounced effect. Rafael Repullo felt that labour economics tended to have excessively simplistic models of wage setting, despite its frequent claim that the labour market needs special models.

Georges de Menil was not convinced that there is an inconsistency between the relative stability of the Kaitz index and the growing level of unemployment. In a stochastic world it is the relative rigidity of the Kaitz index that proves costly. In order to appreciate the true cost of minimum wages, it would be more instructive to examine particular episodes where the minimum wage was changed. Naturally, given the downward stickiness of wages, there might be more information in episodes where minimum wages were increased rather than decreased. He wondered if it was somehow possible to retain the legislated minimum wages at their current levels and yet allow workers to work for a lower wage if they were so willing. Frederick van der Ploeg thought this was unlikely to succeed. Given that 
legislated minimum wages are closely tied to the level of unemployment benefit, workers have little incentive to work for a lower wage. For him the principal policy issue was: how do we reduce the gap between the legislated minimum wage and the agreed minimum wage? He felt that wage demands could be moderated by offering tax concessions around the minimum wage, and tax credits to firms for training. Alessandra Casella thought that the excessive concern with the pure employment consequences of minimum wages ignored the potential impact of minimum wages on other variables, such as poverty, health and even long-term growth.

\section{TECHNICAL APPENDIX}

Our theoretical framework is based on a simplified version of the model in Dickens et al. (1994a).$^{12}$ Assume firm i has a log marginal revenue product of labour curve given by:

$m r p l_{i}=a_{i}-\eta n_{i}$

where $n$ is $\log$ employment and $a$ is a shock to the MRPL which reflects demand or productivity shocks. We assume that these shock are normally distributed across furms with mean $\mu$ and variance $\sigma^{2}$. If the labour market were perfectly competitive, the elasticity of labour demand would be $(1 / \eta)$. Labour supply to the furm is given by:

$w_{i}=\theta w+\varepsilon n_{i}+b$

where $w_{i}$ is the log wage in firm $i$ and $w$ is the average log wage. If the labour market is perfectly competitive then $\varepsilon=0$, but if $\varepsilon>0$ then the market is, to some extent, monopsonistic. The dependence of labour supply on the average wage gives us a simple way of modelling the spillover effect of the minimum wage on wages in other firms: it implies that the elasticity of the labour supply curve facing the frm is more elastic than the labour supply curve in the economy as a whole. If $\theta=1$ then aggregate labour supply is completely inelastic; $b$ is a labour supply shock which, for simplicity, we assume is constant across firms.

First, consider the equilibrium when there are no minimum wages. Each firm chooses the level of employment where the $\log M R P L$ equals the log marginal cost of labour, which from equation (A2) is given by:

$m c l_{i}=\ln (1+\varepsilon)+w_{i}$

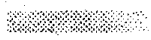

${ }^{12}$ We assume that all firms face the same labour supply curve and that cconomy-wide averages are averages across furms of the logs of the relevant variables (this keeps the mathematics simple). One must be a little careful in using this version of the model to analyse the compecitive case, since our assumptions imply that there would be no wage dispersion in this ase. See Dickens et al (1994a).
} 
Equating (AI) and (A3) gives employment in firm $i$ (for a given average wage) as:

$n_{i}=\frac{\left[a_{i}-\ln (1+\varepsilon)\right]-(\theta w+b)}{\eta+\varepsilon}=n\left(w, a_{i}, b\right)$

and from (A2) the wage is:

$w_{i}=\frac{\varepsilon\left[a_{i}-\ln (1+\varepsilon)\right]+\eta(\theta w+b)}{\eta+\varepsilon} \equiv v\left(w, a_{i}, b\right)$

Equations (A4) and (A5) are easy to understand. Revenue shocks, $a$, have a positive effect on employment, while supply shocks, $b$, have a negative effect. In contrast, both $a$ and $b$ are positively related to wages, although, as we would expect, $a$ has an effect only to the extent that the labour market is not perfectly competitive (where $\varepsilon>0)$.

One can solve the model by then taking expectations of $(A 5)$ and using the assumption that $E\left(w_{i}\right)=w$. We can derive:

$w^{m}=\frac{\varepsilon[\mu-\ln (1+\varepsilon)]+\eta b}{\varepsilon+\eta(1-\theta)}$

and the average log employment across firms is:

$n^{m}=\frac{(1-\theta)[\mu-\ln (1+\varepsilon)]-b}{\varepsilon+\eta(1-\theta)}$

Now consider what happens if a minimum wage of $w^{*}$ is introduced. This will have different effects on different firms according to their different productivity shocks. Some firms will pay above the minimum, so that equations (A4) and (A5) will continue to be relevant. Note that if $\theta \neq 0$, the change in $w$ caused by the minimum wage will mean that the set of firms initially paying above $w^{*}$ will not be the same as the ones now paying above $w^{*}$, and that although these firms pay above the minimum, they are still affected by it. A firm will be in this regime if the desired wage as given by equation (A5) is above $w^{*}$, i.e. if $a_{i} \geqslant a^{*}$ where $a^{*}$ satisfies:

$w^{*}=\frac{\eta[\theta w+b]+\varepsilon\left[a^{*}-\ln (1+\varepsilon)\right]}{\eta+\varepsilon}$

For firms with $a_{i} \geqslant a^{*}$, we will have, using equation (A.5):

$w_{i}\left(a_{i}\right)=\frac{\varepsilon}{\eta+\varepsilon}\left(a_{i}-a^{*}\right)+v\left(w, a^{*}, b\right)=\frac{\varepsilon}{\eta+\varepsilon}\left(a_{i}-a^{*}\right)+w^{*}$

All firms with $a_{i} \leqslant a^{*}$ will pay the minimum wage $w^{*}$. The fraction of firms paying the minimum wage (i.e. the spike) will be given by $\Phi\left(z^{*}\right)$ where $z^{*}=\left(a^{*}-\mu\right) / \sigma$. 
Putting this information together we have that the expected wage is given by:

$$
\begin{aligned}
w & =\Phi\left(z^{*}\right) w^{*}+\left[1-\Phi\left(z^{*}\right)\right]\left(w^{*}+\frac{\varepsilon}{\eta+\varepsilon} E\left(a_{i}-a^{*} \mid a_{i} \geqslant a^{*}\right)\right) \\
& =w^{*}+\frac{\varepsilon \sigma}{\varepsilon+\eta}\left(r-z^{*}\left[1-\Phi\left(z^{*}\right)\right]+\phi\left(z^{*}\right)\right)
\end{aligned}
$$

Equation (A10) can be solved for the average wage in terms of the minimum wage. Although there is generally no explicit analytical solution for $w$ in terms of the minimum, we can still derive several useful conclusions.

First, the effect of an increase in the minimum wage on the average wage is given by:

$$
\frac{\partial w}{\partial w^{*}}=\frac{\Phi^{*}}{1-\frac{\eta \theta\left(1-\Phi^{*}\right)}{\varepsilon+\eta}}<1
$$

Hence an increase in the minimum wage leads to a less than proportional increase in the average wage, so that the Kaitz index will rise. This is the basis for the claim in the paper that we would expect rises in the minimum wage always to be associated with rises in the Kaitz index ${ }^{13}$ One can also see that a given rise in the minimum wage has a larger effect on the average wage, the larger is the spillover effect, $\theta$.

Second, as $\left(w^{*}-w\right)$ is the log of the Kaitz index and $\Phi\left(z^{*}\right)$ is a measure of the spike, one can think of equation (A10) as giving a relationship between the Kaitz. index and the spike. It shows that, other things being equal, a rise in the Kaitz index will be associated with a rise in the spike. But equation (A10) also shows that the relationship between the Kaitz index and the spike is influenced by the parameters of the economy, so that, for example, an increase in $\sigma$ will, for a given spike, lead to a reduction in the Kaitz index.

Now let us turn to employment. In the unconstrained firms we will have employment given by equation (A4), which can be written as:

$n_{1}\left(a_{1}\right)=n\left(w, a^{*}, b\right)+\frac{1}{\varepsilon+\eta}\left(a_{i}-a^{*}\right)$

Now consider firms with $a_{i} \leqslant q^{*}$, i.e. those which pay the minimum wage Employment in these firms will be determined by the minimum of labour demand

\section{एका}

\footnotetext{
${ }^{13}$ This result is based on the assumption that the wage distribution with a minimum wage is a censored distribution. If one were convinced that the minimum wage destroyed all jobs that would have paid below the minimum, it would be more appropriate to use a cruncated distribution. One can then show that the elasticity of the average wage with respect to the mirimum wage is less than 1 if $(1-F(w))$ is log-concave, where $F$ is the distribution function of wages. This condition is satisfied for most wage distributions used.
} 
and supply. Labour supply will be given by $n\left(w, a^{*}, b\right)$, since the firm at the boundary between these two regions will be on its labour supply curve. Employment will be supply determined if the marginal revenue product of labour supply exceeds the minimum wage, i.e. if:

$a_{i}-\frac{\eta}{\varepsilon}\left(w^{*}-\theta w-b\right) \geqslant w^{*}$

which can be rearranged to yield:

$a_{:} \geqslant a^{*}-\ln (1+\varepsilon)=\hat{a}$

Hence, firms for whom $a^{*}-\ln (1+\varepsilon) \leqslant a_{i} \leqslant a^{*}$ pay the minimum wage and have employment equal to supply $n\left(w, a^{*}, b\right)$. Firms for whom $a^{*}-\ln (1+\varepsilon) \geqslant a_{i}$ will have employment demand determined, in which case, using equation (Al), employment can be written as:

$n\left(a_{i}\right)=n\left(w, a^{*}, b\right)+\frac{1}{\eta}\left(a_{i}-a^{*}\right)$

Combining equations (A15) and (A|2), we have that average employment is given by:

$$
\begin{aligned}
n=E\left(n_{i}\right)= & n\left(w, a^{*}, b\right)+\frac{1}{\eta+\varepsilon}\left(1-\Phi\left(z^{*}\right)\right) \cdot E\left(a_{i}-a^{*} \mid a_{i} \geqslant a^{*}\right) \\
& +\frac{1}{\eta} \Phi(\hat{z}) E\left(a_{i}-\hat{a} \mid a_{i} \leqslant \hat{a}\right) \\
= & n\left(w, a^{*}, b\right)+\frac{\sigma}{\eta+\varepsilon}\left(r-z^{*}\left(1-\Phi\left(z^{*}\right)\right)+\phi\left(z^{*}\right)\right)-\frac{\sigma}{\eta}(\hat{z} \Phi(\hat{z})+\phi(\hat{z}))
\end{aligned}
$$

Now, using equation (A4), we have that:

$$
\begin{aligned}
n\left(w, a^{*}, b\right) & =n(w, \mu, b)+\frac{a^{*}-\mu}{\eta+\varepsilon}=n(w, \mu, b)+\frac{\sigma z^{*}}{\eta+\varepsilon} \\
& =n\left(w^{m}, \mu, b\right)-\frac{\theta\left(w-w^{m}\right)}{\eta+\varepsilon}+\frac{\sigma z^{*}}{\eta+\varepsilon}
\end{aligned}
$$

And, using equations (A6) and (A8), we can derive:

$\left(w-w^{m}\right)=\frac{\varepsilon \sigma z^{*}-(\eta+\varepsilon)\left(w^{*}-w\right)}{\varepsilon+\eta(1-\theta)}$

Combining equations (AI6), (A17) and (A18) we have that:

$n-n^{m}=\frac{\sigma(1-\theta)}{\varepsilon+\eta(1-\theta)}\left(\left(z^{*} \Phi\left(z^{*}\right)+\phi\left(z^{*}\right)\right)-\frac{\sigma}{\eta}(\hat{z} \Phi(\hat{z})+\phi(\hat{z}))\right)$ 
We can use this relationship to explain and evaluate the different approaches to estimating the employment effects of the minimum wage.

\section{A1. Time-series and panel studies}

The idea here is to estimate an equation like (A19) including measures of demand and supply shocks to control for $n^{m}$ and then the Kaitz index to pick up the minimum wage effects. Note that equation (A19) shows that, given the parameters of the.economy, the Kaitz index or the spike is a sufficient statistic for the employment loss or gain attributable to the minimum wage independent of demand and supply shocks, so the Kaitz index is a sensible measure to use of the impact of the minimum wage.

\section{A2. The 'natural experiment' approach}

The idea here is to take two markets, one with a big change in the minimum wage and one without, but which might be expected to have similar demand and supply shocks. Taking the difference in difference between these markets in equation (A19) then allows an estimate of the effect of minimum wages.

\section{A3. The 'differential impact' approach}

Here, the idea is to look at the relationship between employment changes and the impact of minimum wages across agents in a single market. There are potential problems with this. The problem is that the model predicts a non-monotonic relationship between employment change and the impact of the minimum wage. To see this, consider the effect of introducing a minimum wage. Assume, for simplicity, that $\theta=0$. The line $\mathcal{N} \mathcal{N}$ gives the relationship between employment and

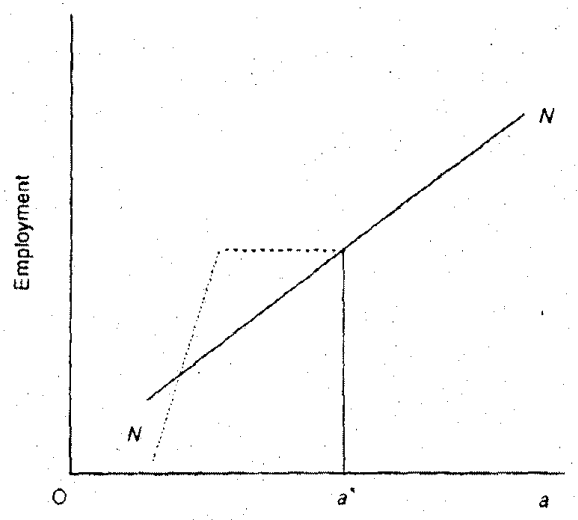

Figure A1. The impact of minimum wages in our theoretical model 
$a_{i}$ before the introduction of a minimum wage. Now consider the imposition of a minimum wage. Employment in the firms above $a^{*}$ will be unaffected, those immediately below $a^{*}$ will have constant employment and those with sufficiently low $a_{i}$ will have employment falling. The differential inpact approach examines the slope of the relationship between the gap between the two lines (the employment change) and the gap between the initial wage and the minimum wage. This is not the same as the total employment change, which is the integral between the two employment lines. Figure $\mathrm{Al}$ needs modification if $\theta$ is not zero, since then $\mathcal{N N}$ itself moves down with the minimum wage, but the basic ideas remain the same. However, it is unclear how serious this problem is because no evidence of such a non-monotonic relationship has ever been presented.

\section{A4. The Meyer-Wise approach}

The model presented above can be used to illustrate the problems associated with the Meyer-Wise approach. As shown in Dickens et al. (1994b), this approach estimates the wage distribution truncated by the minimum. The proportion of workers who are predicted to have wages below the minimum is then compared with the actual proportion paid the minimum. In the model presented here, equation (A9) can be used to show that for those paid above the minimum wage the distribution of wages is a truncation of the normal distribution given by:

$w_{i}-\mathcal{N}\left(w^{*}+\frac{\varepsilon\left(\mu-a^{*}\right)}{\varepsilon+\eta}, \frac{\varepsilon^{2} \sigma^{2}}{(\varepsilon+\eta)^{2}}\right)$

where the truncation is at $w^{*}$. Assuming that the researcher estimates the correct distribution, the proportion of firms which should be paying wages at or below the minimum is given by $\boldsymbol{\Phi}\left(\left(a^{*}-\mu\right) / \sigma\right)$. This is the actual proportion paying below the minimum, so the methodology of Meyer-Wise would induce the researcher to conclude that there are no employment effects - a conclusion that is generally wrong.

\section{REFERENCES}

Abowd, J. M., F. Kramarz, T. Lemieux and D. N. Margolis (1995). 'Minimum Wages and Youth Unemployment in the United States', presented at the CIRANO Summer Workshop on Unemployment in the 1980s, July.

Albaek, K and E.S. Madsen (1987): 'Wage Distributions and Employment Effects of the Danish Minimum Wage', in R. Lund and P. Pederson (eds.), Studies in Unemployment, Samfundslitteratur.

- (1989). 'Den solidariske lonpolitik og beskaefitgelsen af lavilonnede', Nationalokonomisk Tudsskzit.

Bazen, S. and J. P. Marrin (1991). 'L'impact du salaire minimum sur les salaires et l'emploi des jeunes et des adultes en France', Retue Economique de l'OCDE.

Bazen, S., G. Benhayoun and N. Skourias (1995). "The lmpact of Minimum Wiages in France: A Regional Approach', IERSO, Universite de Bordeaux IV

Benhayoun, G. (1994). 'The Impact of Minimum Wages on Youth Employment in France Revisited', intemational Joumal of Manpower.

Brown, C., C. Gilroy and A. Kohen (1982). 'The Effect of the Minimurn Wage on Employment and Unemployment', Jounal of Economic Literature. 
Canuc, P. and J. Michel (1996). 'Minimum Wage, Unemployment and Growth', European Economic Review, fortheoming.

Calvo, G. and S. Wellisz (1979). 'Hierarchy, Ability and Income Distribution', Joumal of Political Economy.

Card, D. (1992a). "Using Regional Variations in Wages to Measure the Effects of the Federal Minimum

Wage', Industrial and Labor Relations Reviav.

- (1992b). 'Do Mirimum Wages Reduce Employment? A Case Study of California, 1987--89', Industrial and Labor Relations Review.

Card, D. and A Krueger (1994). 'Minimum Wages and Employment A Case Study of the Fast Food Industry in New Jersey and Pennsylvania', American Economic Review.

- (1995). Myth and Meastocment: The Now Economics of the Minimuan Wage, Princeton University Press, Princeton, N].

Card, D., F. Kramarz and T. Lemieux (1995). 'Changes in the Relative Structure of Wages and Employment: A Comparison of the United States, Canada and France', unpublished, Princeton University.

Combautt, P. (1995). 'Les Salaires au Smic en Juillet 1990', LNSEE.

Currie, J. and B. Fallick (1994). The Minimum Wage and the Employment of Youth: Evidence from the NLSY', UCLA Working Paper.

Dickens, R., S. Machin and A. Manning (1994a). 'The Effects of Minimum Wages on Employment: Theory and Evidence from Britain', LSE CEP Discussion Paper.

- (1994b). 'Estimating the Effect of Minimum Wages on Employment from the Distribution of Wages: A Critical Vicw', LSE CEP Discussion Paper.

Dickens, R, S. Machin, A Manning. D. Metcalf, J. Wadsworth and S. Woodland (1995) 'Minimum Wages and UK Agriculture', Joumal of Agricultural Economacs.

Freeman, R.B. (1996). 'The Minimum Wage as a Redistributive Tool', Economic 7oumal

Garcia, $S_{;}$F. Goerlich and V. Orts (1994). Macro Magritudes Básicas a Nivel Sectorial de la Industria Espaflola: Series Historicas', Economia Industrial, 27.

Gelot, O. (1995). 'Youch Employment Programs in France', paper presented at NBER, 1995.

Grossman, J.B. (1983). 'The Impact of the Minimum Wage on Other Wages', Foumal of Human Resources.

Guesnerie, R. and X. Raberts (1987). 'Minimum Wage Legislation as a Second Best Policy', European Eronomic Review.

Koning, P., G. Ridder and G. van den Berg (1994). 'Stnucural and Fricrional Unemployment in an Equilibrium Search Model with Heterogeneous Agents', Free University of Amsterdam Research Memorandum 1994-52.

Machin, S. and A. Manning (1994). 'Minimum Wages, Wage Dispersion and Employment: Evidence from the UK Wages Councils', Industrial and Labor Relations Reviow.

Manning, Alan (1995). 'How Do We Know thac Real Wages are Too High?', Quarlerly Joumal of Economicr.

- (1996). 'The Equal Pay Act as an Experiment to Test Theories of the Labour Market', Economica, forcheoming

Marceau, N, and R. Boadway (1994). Minimum Wage Legislation and Unemploytnent Insurance as Instruments for Redistribution', Scandinawion Jownual of Economics.

Meyer, R. and D. Wise (1983a). 'The Effects of the Minimum Wage on the Employment and Eamings of Youth'; Journal of Labor Ecoromics.

- (1983b), 'Discontinuous Distributions and Missing Persons: The Minimum Wage and Unemployed Youth', Econometrica.

Mot, E. and C. Teulings (1990). "The Employment and Wage Effects of Minimum Wage Reductions for Young People in the Netherlands', unpublished, University of Amsterdam.

- (1995). 'The Effect of New Jerseyt Minimum Wage Increase on Fast-Food Employment: A Reevaluacion using Payroll Records', NBER Working Paper No. 5224.

Nickell, S. and B. Bell (1995). 'The Collapse in the Demand for the Unskilled Across the OECD', Oxford Raviaw of Economic Policy.

Nolan, B. (1993). 'Low Pay in Ireland', ESRI General Research Paper No. 159, Dublin

OECD (1994). Jobs Sudy, Paris.

Ostros, T. (1994). 'Do Minimum Wages Matter? The Case of Swedish Mining and Manufacturing', unpublished, Uppsala University.

Rebitzer, J. and L. Taylor (1995). "The Consequences of Minimum Wage Laws. Some New Theoretical Ideas', Fournal of Public Economics.

Saint-Paul, G. (1994). 'Do Labor Market Rigidities Fulfill Distributional Objectives?' IMF Staff Papers.

Schmitt, J. (1996). 'The Minimum Wage and Job Loss: Opponents of Wage Hike Find No Effect', Economic Policy Instrute Briefing Paper, Washington, DC

Sutherland, H. (1995). 'Minimum Wage Benefits', Naw Economy.

Uri, N. D. and M.J. Mixon (1980). 'An Economic Analysis of the Determinants of Minimum Wage Voting Behavior', Journal of Law and Economics.

Valdes, T. (1992). 'Diseno del Panel de Declarantes de IRPF y Patrimonios', in Las Rentas de las Familias y su Tributacion, Instituto de Estudio Fiscales.

van Soest, A. (1989). 'Minimum Wage Rates and Unemployment in the Netherlands', De Economist

- (1994). 'Youch Mirimum Wage Rates: The Dutch Experience', International Joumal of Manpower. 